\title{
Achievement Differences and School Type: The Role of School Climate, Teacher Certification, and Instruction
}

\author{
SARAH THEULE LUBIENSKI, CHRISTOPHER LUBIENSKI, and \\ CORINNA CRAWFORD CRANE \\ University of Illinois at Urbana-Champaign
}

\begin{abstract}
Recent analyses challenge common wisdom regarding the superiority of private schools relative to public schools, raising questions about the role of school processes and climate in shaping achievement in different types of schools. While holding demographic factors constant, this multilevel analysis of National Assessment of Educational Progress (NAEP) mathematics data on over 270,000 fourth and eighth graders in over 10,000 schools examines differences among schools on five critical factors: (1) school size, (2) class size, (3) school climate/ parental involvement, (4) teacher certification, and (5) instructional practices. This study provides nationally representative evidence that both teacher certification and some reform-oriented mathematics teaching practices correlate positively with achievement and are more prevalent in public schools than in demographically similar private schools. Additionally, smaller class size, more prevalent in private schools, is significantly correlated with achievement.
\end{abstract}

In recent decades, policy makers and reformers have proceeded from a belief in a positive "private school effect" in seeking structural remedies that can boost student achievement. This thinking is reflected, for instance, in the school choice movement, and in the No Child Left Behind (NCLB) Act, which uses choice sanctions and charter status to prod low-performing public schools. Although well-grounded in the research literature, this notion of a private school effect has recently been challenged by large-scale studies showing public schools performing at a level equal to and, in many cases, beyond that of private schools, once student demographics are considered. However, these new analyses paid little attention to the role of school processes in understanding achievement differences across school types. This analysis, using the largest nationally representative data set available to date, examines the degree

Electronically published July 30, 2008

American Journal of Education 115 (November 2008)

(C) 2008 by The University of Chicago. All rights reserved.

0195-6744/2008/11501-0004\$10.00

NOVEMBER 2008 


\section{Achievement Differences and School Type}

to which differences in school practices and climate account for achievement disparities between public schools and Catholic, Lutheran, conservative Christian, other private, and charter schools.

\section{Understanding Achievement in Public and Private Schools}

Assumptions about a direct link between school governance structures and academic outcomes are motivated largely by the prominence of market theory (Davies and Quirke 2004; Smith 2003; see, e.g., Chubb and More 1990b; Walberg and Bast 2003). Under this logic, public schools are hindered in their effectiveness by bureaucratic administration and an exclusive claim to public funds, while more efficient and innovative private schools must compete and respond to consumers in order to survive. This thinking is evident in the charter school movement and voucher plans, which seek to position schools in a more competitive environment in order to create the opportunities and incentives for them to innovate and improve achievement. The federal NCLB reform also reflects this thinking in terms of the use of school reorganization, parental choice, and nonpublic service providers, as well as the threat of charter school status, to force improvement in school effectiveness.

While market theory offers a compelling critique of, and prominent prescription for, American education, it is largely silent on the actual educational processes within schools. In the logic of market theory, parents determine what types of schools they prefer, and the competitive incentives resulting from those preferences force schools to develop more effective processes. Market theory focuses largely on external incentives and institutional issues, and the logic

SARAH Theule Lubienski is an associate professor in the Department of Curriculum and Instruction at the University of Illinois at Urbana-Champaign. Her scholarship centers around intersections of mathematics achievement, instruction, equity, and reform. She recently served as chair of the National Assessment of Educational Progress (NAEP) Studies Special Interest Group of the American Educational Research Association. Christopher Lubienski is an associate professor and fellow with the Forum on the Future of Public Education at the University of Illinois, where he studies education policy and reform. His work on the political economy of charter schools, vouchers, and choice has appeared in American Educational Research Fournal, the Peabody Fournal of Education, Education and Urban Society, and the Phi Delta Kappan. CorinnA CRAWFORD CRANE is a doctoral student in the College of Education at the University of Illinois at Urbana-Champaign. Her interests include mathematics education, large-scale data analysis, and education policy. 


\section{Lubienski, Lubienski, and Crane}

posits only a "black box" in the place of the actual internal processes of schools (McEwan 2000). However, school structures themselves do not teach children, and it might be that the nature of a school's management holds less immediate interest for a child than does, say, the qualifications of the teacher in the classroom, the type of instruction, or the number of classmates - all topics of some interest in current discussions of education reform.

While there is a strong theoretical impetus, belief in the superiority of private schools is also based, in part, on past studies involving the 1980 High School and Beyond (HSB) data set. These highly respected studies found that private schools were more effective than public schools at boosting student achievement, even after socioeconomic differences were considered (Chubb and Moe 1990a; Coleman and Hoffer 1987; Coleman et al. 1982). More nuanced HSB research went further, pointing to particular aspects of private schools that appeared beneficial, such as a more productive academic climate found in Catholic schools (Bryk et al. 1993).

However, in more recent studies using National Assessment of Educational Progress (NAEP) data, Lubienski and Lubienski (2006) found that mathematics achievement in (noncharter) public schools was slightly higher than that in demographically similar private schools. Subsequently, in a study commissioned by the federal Department of Education, Braun et al. (2006) reported similar findings regarding NAEP achievement in public and private schools. A handful of longitudinal analyses have pointed in the same direction, raising questions about assumptions that structural aspects of the private school sector necessarily lead to better learning outcomes (Lubienski, Crane, and Lubienski 2008; Reardon, Cheadle, and Robinson 2008; Scott et al. 1995; Taningco 2006).

While such studies offer some insights into achievement differences by school type, they tell us little about the degree to which education itself differs. Although some evidence suggests that school practices tend to vary by school type (Alt and Peter 2002; Chandler 1999), Benveniste et al. (2003) suggest that differences in school climate and practices might be related more to social class than school sector.

This study determines the degree to which internal aspects of schools are distributed across school types and the extent to which such aspects correlate with student achievement. In this study, we focus on achievement in mathematics - a subject generally thought to be less influenced by family background, and more by school effects, than other subjects (Bryk et al. 1993; Heyneman 2005). This analysis holds significance for current education debates and reform efforts, particularly in analyzing the relationship (or lack thereof) between achievement and controversial factors such as teacher certification, class size, instructional approaches, and parental involvement. 


\section{Achievement Differences and School Type}

School Characteristics, Climate, and Practices

Scholars have pointed to several school-level characteristics that may affect student achievement. Here we very briefly review the literature regarding those aspects of schools that are measured by NAEP and that prior research suggests might be related to achievement and school type. Other potentially important variables, such as school funding, are not measured by NAEP and are therefore not included in this analysis.

\section{School Size}

In general, private schools tend to be smaller than public schools (Anderson and Resnick 1997; Choy 1997). Smaller schools are often found to be associated with higher school performance (Darling-Hammond 2000). In a study of almost 6,500 at-risk eighth-grade students nationwide, Finn and Voelkl (1993) found that smaller school size was positively associated with a more nurturing environment and greater minority student engagement. Other scholars, however, argue that the relationship between school size and achievement is complex; it may be nonlinear and might vary by rural/urban context (e.g., Howley and Howley 2004 and Lee 2004).

\section{Class Size}

The best evidence available indicates that smaller class sizes boost achievement (Finn and Achilles 1999; Krueger and Whitmore 2001; Mosteller 1996). Still, some dispute that connection (Hanushek 1999; Hoxby 2000). Of course, smaller classes are expensive, and the issue is therefore highly politicized.

Data from the National Center for Education Statistics (NCES) Schools and Staffing Survey indicate that, on average, private school teachers have fewer students (19.6) than do public school teachers (23.2; Anderson and Resnick 1997). Indeed, smaller class size is probably one reason parents choose private schools.

School Climate, Community, and Parental Involvement

One of the prominent themes emerging from the HSB studies was the importance of a sense of community within Catholic schools (Bryk et al. 1993). Subsequent research has noted that strong relationships and shared beliefs within a school community can enhance teaching and learning (Ban- 


\section{Lubienski, Lubienski, and Crane}

dura 1993; Bryk and Schneider 2002; Goddard et al. 2000). Also, a fiveyear study of school restructuring efforts indicated that supportive leaders, knowledgeable teachers, mutual respect, and willingness to improve are more necessary for professional community than are structural considerations (Newmann and Wehlage 1995). Most recently in a study of 96 high schools, Hoy et al. (2006) found a relationship between achievement and "academic optimism," a combination of a school's academic emphasis, collective efficacy, and teacher-parent trust.

A closely related factor is parent involvement. Some scholars have found that parents' involvement with their children's education benefits students, schools, and the parents themselves (Comer 2005; Henderson and Mapp 2002). However, a recent study by Lee and Bowen (2006) examined several different types of parent involvement and found that only parent involvement within schools (conference attendance, volunteer work) and parent expectations of success were significantly associated with achievement. Parent support at home (helping with homework, discussing educational topics, and managing children's activities) was not significantly related.

Some aspects of school climate have been found to differ by school type. For instance, private school teachers tend to report more autonomy in their work, a greater sense of community within their schools, and more support from their principals (Anderson and Resnick 1997; Bryk et al. 1993; Choy 1997). Still, teacher turnover tends to be higher in private schools (Choy 1997; Ingersoll 2001).

Public high school teachers report that their students have greater absenteeism and poorer attitudes toward learning (Choy 1997). Additionally, private school parents tend to be more involved than their public school counterparts (Bryk et al. 1993; Choy 1997). In contrast, Rothstein et al. (1999) found that parent accountability and participation were much more associated with the social class of the parents than with school sector; low parent participation was a problem in low-income schools regardless of sector.

\section{Teacher Certification and Development}

Some scholars argue that there is little evidence to justify the almost exclusive claim that teacher preparation institutions make on certification (Hess 2006; Moe 2005). On the other hand, some research suggests that teacher certification and related college courses have a positive impact on student achievement, particularly in mathematics (Darling-Hammond 2000; Goldhaber and Brewer 2000; Monk, 1994; Wayne and Youngs 2003). Greenwald et al. (1996) argued from their review of 60 studies that there is a substantial positive relationship between student achievement and school inputs, including teacher 


\section{Achievement Differences and School Type}

qualifications; however, Hanushek (1996) critiqued their synthesis. Given that private schools are not required to hire certified teachers, there are fewer regularly certified teachers in private schools (U.S. Department of Education 2004).

In a related vein, there has been debate regarding the value of various forms of professional development. Overall, evidence indicates that professional development can enhance both teacher practices and student achievement, particularly when it focuses on increasing teachers' understanding of children's mathematical thinking, as well as on the mathematics in the curriculum and in the assessments that teachers use (Carpenter et al. 1989; Cohen and Hill 2001; Hill et al. 2005).

\section{Teaching Practices}

Over the past two decades, major changes have occurred in U.S. mathematics education. The National Council of Teachers of Mathematics (NCTM 1989, 2000), has called for mathematics instruction to emphasize student sense making and to de-emphasize rote learning and routine procedures. The NCTM argued that a wider variety of tools (including manipulatives and calculators) should be employed; NCTM also revised K-12 curricular goals to include greater emphasis on measurement, geometry, data analysis/probability, and algebra. The NAEP's teacher survey was designed to assess the extent to which teachers utilize practices aligned with NCTM's recommendations.

Although NAEP mathematics scores have generally risen over the past 15 years (Braswell et al. 2003; Kloosterman and Lester 2004), there has been some debate as to whether these national achievement gains occurred because of, or in spite of, instruction aligned with the NCTM standards - or reformoriented instruction, as it is commonly called. Evidence from schools that have used reform-oriented curricula and pedagogies has generally indicated that students score at least as well as control groups (e.g., Riordan and Noyce 2001; Schoenfeld 2002; Senk and Thompson 2003). However, others have pointed to less encouraging evidence, such as flat scores on NAEP's longterm-trend mathematics test (Loveless and Diperna 2000).

Several of NAEP's reform-oriented, instruction-related variables have been found to correlate with student achievement, including teacher reasoning (Raudenbush et al. 1998), teacher emphasis on nonnumber mathematics strands, collaborative problem solving, and teacher knowledge of the NCTM standards (Lubienski 2006). Additionally, students' agreement with the statements "learning mathematics is mostly memorizing facts" and "there is only one way to solve a math problem" was strongly, negatively correlated with

\section{American Journal of Education}




\section{Lubienski, Lubienski, and Crane}

achievement, even after controlling for demographic differences among students.

There is relatively little data regarding the ways in which instructional practices vary by school type. However, in Chandler's (1999) survey of 336 Ohio schools, slightly more progressive instructional practices (e.g., discovery learning) appeared in Catholic schools, while the most traditional practices occurred in the independent schools. More recently, however, Carbonaro (2006) found that private school kindergarten teachers use mathematics worksheets and textbooks more often than public schoolteachers do. Data from the 1999-2000 Schools and Staffing Survey indicate that private school teachers report having more freedom to choose their own curricular goals and materials (Alt and Peter 2002).

\section{Research Questions}

The research discussed above illuminates some links between school characteristics and achievement and between school characteristics and school

type. However, few studies examined links among school characteristics, school type, and achievement, and most of those that did were conducted with the High School and Beyond data set, now a generation old.

This study utilizes the 2003 Main NAEP data, which involved samples larger than any previous nationally representative assessment of U.S. schools. Specifically, we addressed the following questions:

- How do school climate, teacher qualifications, and instructional practices differ by school type?

- Which school climate and instruction-related variables correlate positively with mathematics achievement? How might these explain differences in achievement among public and private schools?

This study used hierarchical linear modeling (HLM) to examine how differences in particular school practices might account for the surprising differences in public and private school achievement previously identified in the 2003 NAEP data. Although charter schools were also included in the analysis, those results are not focal here due to space constraints.

\section{Method}

This study was conducted with the raw, restricted-access 2003 Main NAEP mathematics data (the most recent available for secondary analysis at the time of this study). This study was the second phase of a two-part study, with the first phase focusing on achievement differences by school type and this second 


\section{Achievement Differences and School Type}

phase examining possible explanations for the differences identified. Details regarding the first phase of this study, including the creation of the demographic variables used here, were published previously (Lubienski and Lubienski 2006) and are therefore only briefly summarized.

\section{The NAEP Samples}

The 2003 Main NAEP mathematics data set included 190,147 fourth graders and 153,189 eighth graders from representative samples of public and private schools (7,485 schools at grade 4 and 6,092 schools at grade 8). Despite NAEP's primary focus on achievement, the sampled students, their teachers, and school administrators complete detailed questionnaires pertaining to school climate and instruction.

Tables 1 and 2 report the fourth- and eighth-grade sample sizes by school type. There were relatively low numbers of Lutheran and conservative Christian schools at both grades. Additionally, the participation rates of some school types did not meet National Center for Education Statistics reporting standards. Specifically, these were "other private schools" (grades 4 and 8), conservative Christian schools (grade 4 only), and charter schools (grade 8 only). ${ }^{1}$ Hence, the findings for these subsamples should be viewed as suggestive, rather than definitive, as to patterns that would hold for the U.S. populations of these schools.

Due to missing data, the samples used in the HLM analyses contained 157,161 students from 6,288 schools at grade 4 and 119,364 students from 4,870 schools at grade 8 . The demographics of the reduced HLM samples were similar to the demographics of the entire NAEP data set, diminishing concerns that missing data biased the study's results. ${ }^{2}$

\section{Variables Included in HLM Models}

In the earlier phase of our study, we began by running a traditional null model (model 1), followed by a model with school-type variables only (model 2). We then added student and school demographics (model 3) to examine the coefficients for various school types once demographic differences were controlled. In this study, we retained these three models and then created nine additional models that added school size (model 4), class size (model 5, available at grade 4 only), school climate (model 6), teacher background (model 7), time spent on mathematics (model 8), teaching practices/emphases (model 9), student beliefs about mathematics (model 10), and student attitudes toward mathematics (model 11), to determine the extent to which school sector-related

\section{American Journal of Education}




\section{Lubienski, Lubienski, and Crane}

achievement differences persisted after the inclusion of the variables. The final model (model 12) included the school type variables and all other variables that were significant in the previous models.

In selecting these variables, our goal was to include all of NAEP's student-, teacher-, and administrator-reported variables that might correlate with achievement and differ by school type, thereby illuminating possible factors underlying achievement differences between schools. Some of these variables were relatively distinct in their meaning (e.g., school size) and were therefore entered into a model alone, while sets of closely related variables were combined and entered as blocks of variables, as follows.

\section{School Type}

Binary variables for Catholic, Lutheran, conservative Christian, and other private schools were used, which then by default allowed comparisons with regular public schools. ${ }^{3}$

\section{Student Demographics}

Binary variables were used for black, Hispanic, American Indian, Asian/ Pacific Islander, ${ }^{4}$ and female students, as well as for limited English proficiency (LEP) students and those with an individualized education plan (IEP). Two variables were used to approximate students' socioeconomic status (SES): their learning resources at home and their free/reduced-price lunch eligibility. The "home resources" composite was created by summing the six relevant items available in the NAEP data set: magazines, newspaper, computer, encyclopedia, atlas, and number of books.

Survey information about individual students' eligibility for free or reducedprice lunches posed a challenge, given that a disproportionate number of private school administrators reported that their school did not participate in the program. To preserve data while also being cautious in imputing eligibility status, we recoded such students as "ineligible" only if their school administrator also reported that less than 5 percent of the school population was eligible for the lunch program or if the student reported having at least five of the six resources that made up the home resources composite (five was higher than the mean for ineligible students). Overall, the recoded students' mean achievement was higher than that of the other lunch-ineligible students within their school type, providing further evidence that the recoding did not negatively bias the performance of private schools. The final "lunch" variable was binary $(0=$ ineligible and $1=$ eligible for free or reduced-price lunches). 


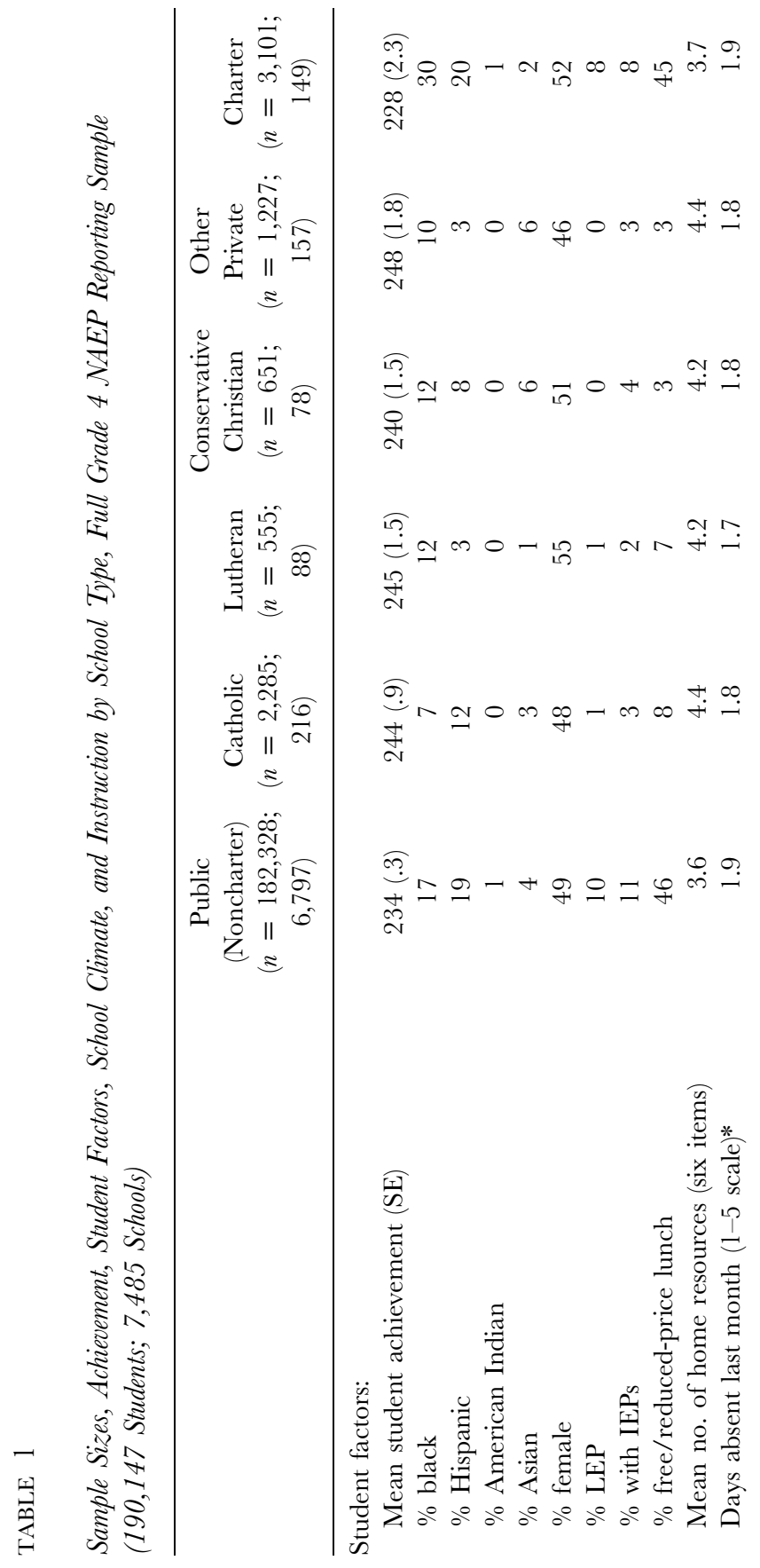




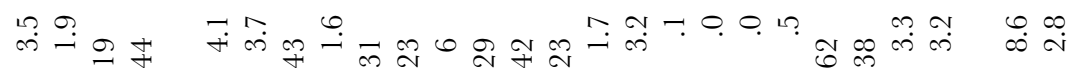

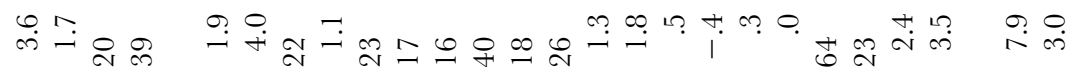

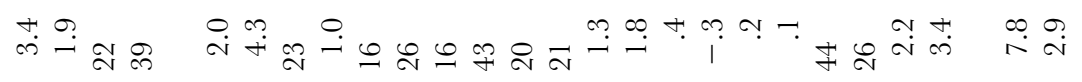

$$
\begin{aligned}
& \text { 吕 }
\end{aligned}
$$

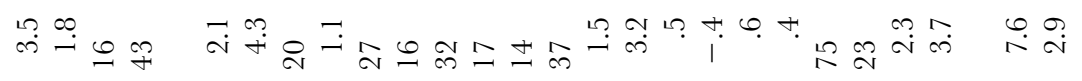

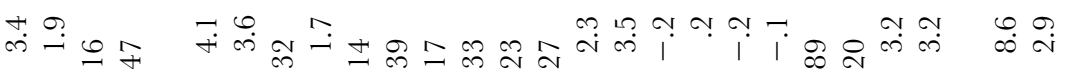

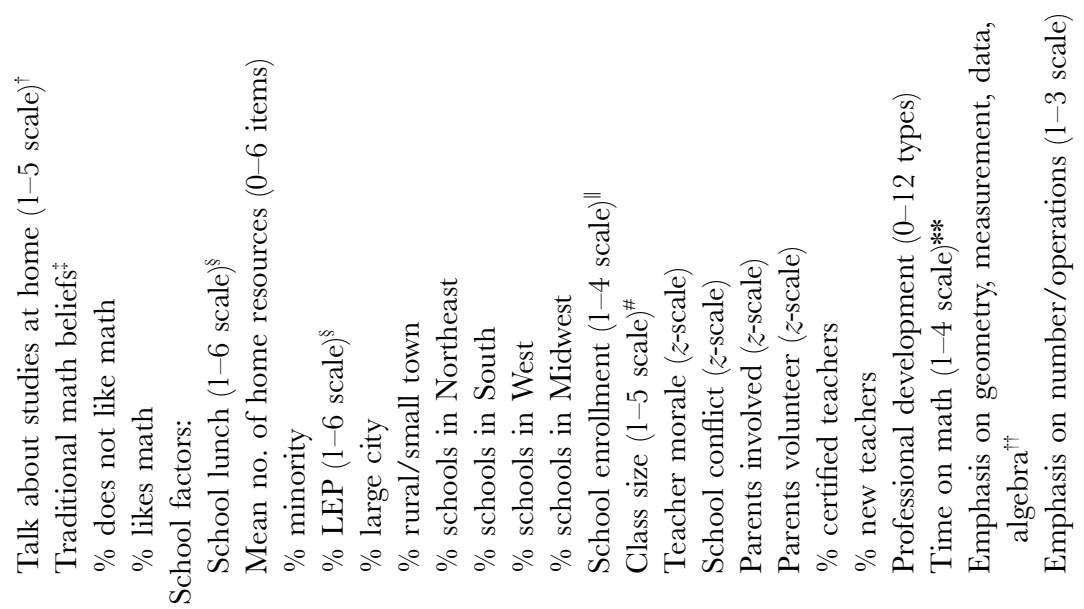




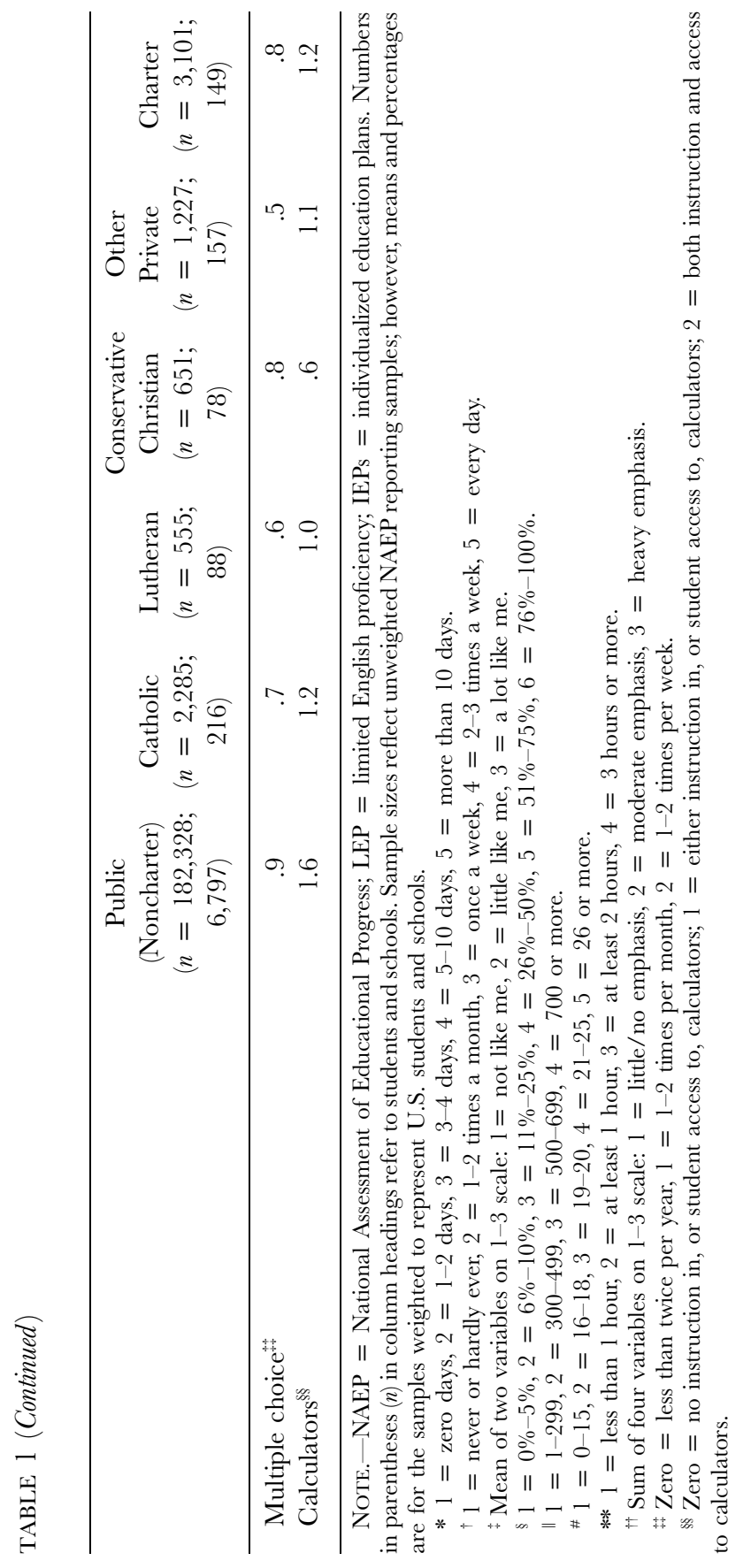




\section{Lubienski, Lubienski, and Crane}

\section{School Demographics}

The home resources composite was aggregated to the school level to provide a school-level "mean home resources" measure. The percentages of students who were black, Hispanic, and American Indian were summed to create a "percentage minority" variable for each school.

The administrator-reported percentage of students eligible for free or reduced-price lunch in the school, as well as the percentage of LEP students, were coded on a 1-6 scale as follows: 0-5 percent, $6-10$ percent, 11-25 percent, $26-50$ percent, $51-75$ percent, $76-100$ percent. $^{5}$

\section{School Location}

Binary variables denoted schools located within large cities and within rural areas/small towns. Similarly, binary variables distinguished among schools located in Northeastern, Southern, and Western (and, by default, Midwestern) portions of the United States.

School Size

School administrators reported student enrollment by selecting one of several categories, which differed at grades 4 and 8 . At grade 4, the four options (coded 1-4) were as follows: 1-299, 300-499, 500-699, and 700 or more. At grade 8, there were five options (coded 1-5): 1-399, 400-599, 600-799, 800-999, and 1,000 or more.

\section{Class Size}

Grade 4 teachers were asked to report the number of students in their math class, using the following categories (coded 1-5): 0-15, 16-18, 19-20, 21-25, and 26 or more. This variable was aggregated to the school level to create a school-level estimate of average class size. Grade 8 teachers were not asked about class size.

\section{School Climate}

There were roughly two dozen NAEP variables that pertained to the climate of the school. Factor analyses were used to identify five clusters of correlated 


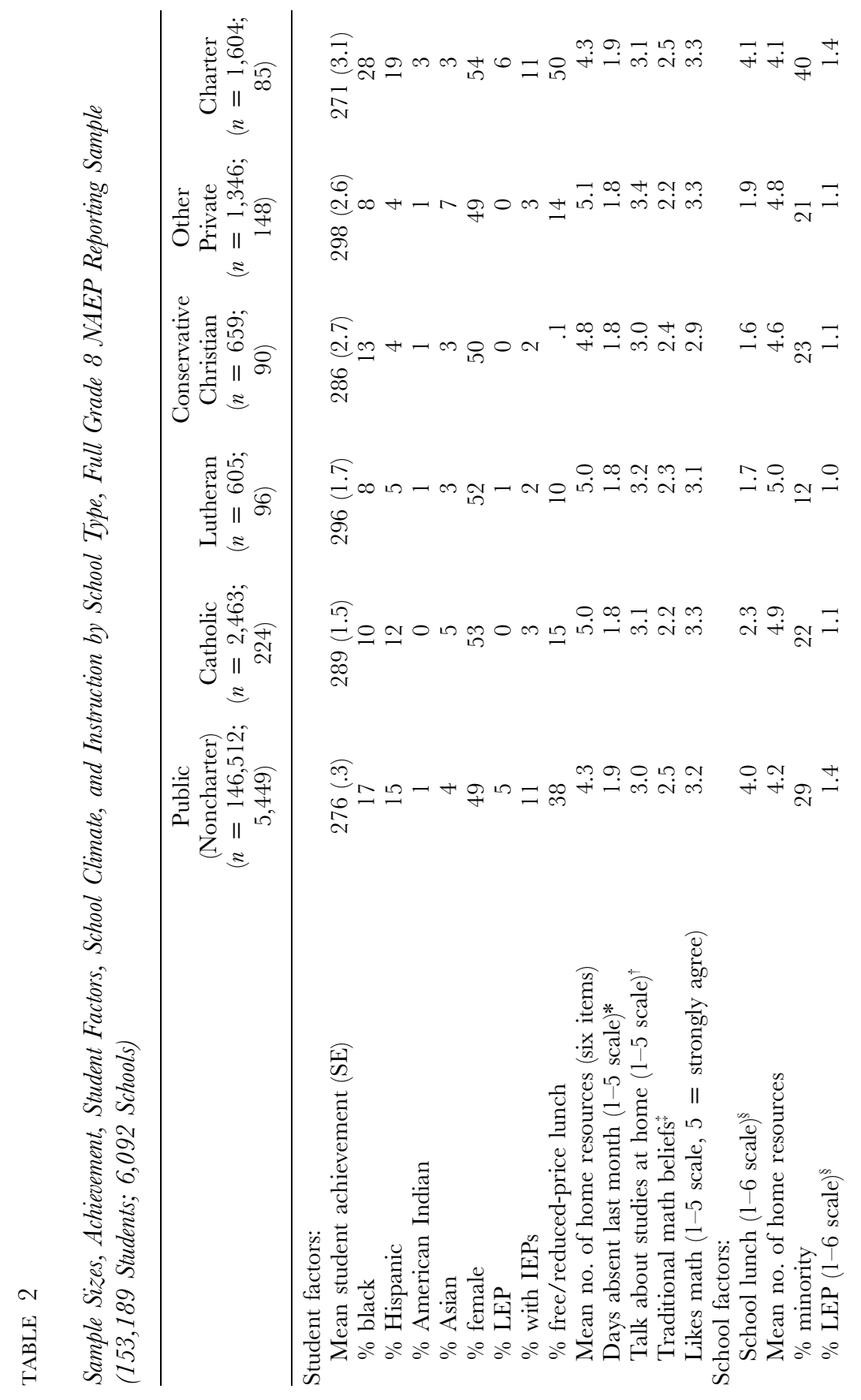




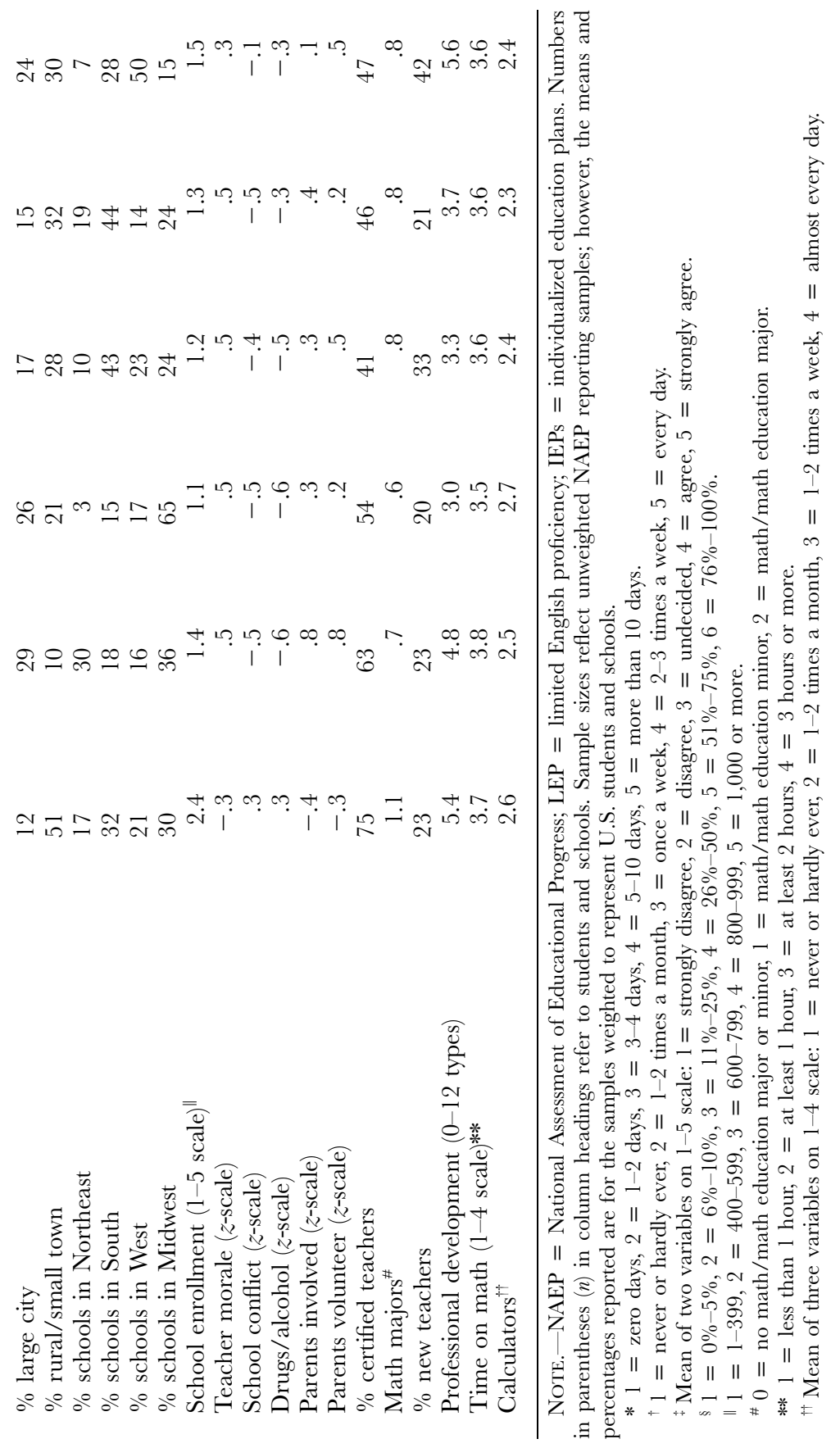




\section{Achievement Differences and School Type}

variables, which were then averaged and standardized to create a $z$-score composite. Some variables included in initial factor analyses did not cluster with others and were then entered into the HLM models individually (as in the case of "school size" and "class size"). Two student-reported variablestalking about schoolwork at home and school attendance-are less direct measures of climate but were related to some of the school climate composites (e.g., parent involvement) and were included as student-level measures of school climate.

Teacher morale cluster. - Four administrator-reported measures of teacher morale were (1) percentage of teachers absent on an average day, (2) extent to which teacher absenteeism is a problem in the school (response options: "not a problem," "minor," "moderate," and "serious"), (3) general teacher morale, and (4) teachers' expectations for student achievement, with the latter two variables measured on a four-point scale, ranging from "very negative" to "very positive."

Conflicts/student behavior cluster.-Administrators reported the extent to which gang activities, physical conflicts among students, student/teacher physical conflicts, race/culture conflicts, vandalism, disregard for school property, and student misbehavior were problematic in their schools. Response options were "not a problem," "minor," "moderate," and "serious").

Drugs/alcohol (grade 8 only).-Three administrator-reported variables indicated the extent to which student use of drugs, alcohol, and tobacco was a problem within the school (again, using the four-point scale, ranging from "not a problem" to "serious").

Parent involvement cluster. - Five administrator-reported variables clustered together: (1) parents attending open house/back-to-school nights, (2) parents attending parent-teacher conferences, (3) parents in parent-teacher organizations, (4) parental support for student achievement, and (5) problem of lack of parent involvement. All of these variables were on a four-point scale.

Parent volunteerism cluster. - At both fourth and eighth grades, variables pertaining to parent volunteerism within the school were not highly correlated with the other forms of parent involvement outlined above. However, four variables pertaining to volunteerism did cluster together and were combined into a single composite. Specifically, the three variables indicating how often ("routinely," "occasionally," or "no") parents served as guest teachers, were used as aides in classrooms, or worked in volunteer programs were combined with the percentage of parents who participated in volunteer programs (fourpoint quartile scale).

Parents talk about schoolwork with students at home. - Students were asked how often they talk about their studies at home with a parent or other adult. Response options (coded 1-5) were "never or hardly ever," "1-2 times a month," "once a week," "2-3 times a week," and "every day."

\section{American Journal of Education}




\section{Lubienski, Lubienski, and Crane}

Student attendance. - Students reported the number of days they were absent from school in the previous month. Response options (coded 1-5) were "none," "1-2 days," "3-4 days," "5-10 days," or "more than 10 days."

\section{Teacher Education and Experience}

Certified teachers.-This teacher-reported variable was aggregated to the school level, indicating the percentage of students in the school who had a certified mathematics teacher.

New teachers. - This binary variable, based on teacher-reported data, indicated whether teachers had zero to four years of experience. This variable was aggregated to the school level.

Professional development.-Teachers were asked whether they had each of 12 forms of professional development within the prior two years, including workshops, mentoring, coteaching, and consultation with a mathematics specialist. The 12 binary variables were summed to indicate the number of the 12 forms encountered (0-12 scale). This is obviously a very rough measure of professional development, providing no indication of the time spent in such activities nor their focus and quality. This variable was aggregated to the school level.

\section{Time on Math}

Fourth-grade teachers were asked how much time they spend on mathematics instruction weekly. Response options (coded 1-4) were "less than 1 hour," "at least 1 hour," "at least 2 hours," and " 3 hours or more." This variable was aggregated to the school level. Eighth-grade teachers did not report their time spent on mathematics (and consequently there were only 11 HLM models created for grade 8, compared with 12 models for grade 4).

\section{Teaching Methods}

NAEP asked fourth-grade teachers about their curricular emphases as well as their use of multiple choice assessments and calculators. These instructionrelated variables were aggregated to the school level to provide estimates of instructional emphases within each school.

Emphasis on geometry, measurement, algebra, and data analysis (grade 4 only).Teachers responded to four questions (1-3 scale) asking whether they place "little/no emphasis," "moderate emphasis," or "heavy emphasis" on each mathematics strand. The resulting four variables were summed to form a 


\section{Achievement Differences and School Type}

composite measure of teachers' emphasis on nonnumber mathematics content areas.

Emphasis on number and operations (grade 4 only).-This variable was measured with the same 1-3 scale as the other four content emphasis variables but did not closely correlate with the others.

Multiple choice assessments (grade 4 only). - Fourth-grade teachers were asked how often they used multiple choice assessments. Responses were coded on a three-point scale, with $0=$ less than twice per year, $1=1-2$ times per month, $2=1-2$ times per week.

Calculators. - At grade 4, teachers were asked whether they provide instruction in the use of calculators and whether their students have access to school calculators. These two binary variables were summed (to create a $0-2$ scale). At grade 8 , teachers were not asked about calculator use, but students were asked how often they use calculators on tests, for classwork, and for mathematics more generally. These variables were coded as follows: $1=$ never or hardly ever, $2=1-2$ times a month, $3=1-2$ times a week, $4=$ almost every day.

\section{Student Beliefs/Attitudes regarding Mathematics}

Students were surveyed regarding their beliefs about and attitude toward mathematics. These variables were included because they likely relate to the mathematics instruction occurring in the schools. Although the questions were similar at both the fourth and eighth grades, the scales differed, with fourth graders asked to indicate whether a statement was "not like me" (coded as one), "a little like me" (coded as two), or "a lot like me" (coded as three). However, at eighth grade, students were given a $1-5$ scale, with $1=$ strongly disagree and $5=$ strongly agree.

Using these response options, fourth and eighth graders rated two statements regarding the nature of mathematics: "learning mathematics is mostly memorizing facts" and "there is only one correct way to solve a mathematics

problem." For the sake of brevity, agreement with these statements is termed "traditional mathematics beliefs" throughout this article.

Students also indicated their agreement with the statement "I like mathematics" at both the fourth and eighth grades. Given the three-point scale at grade 4 for this single variable, we converted it to two binary variables. The grade 8 variable on the five-point scale remained as originally coded.

\section{American Journal of Education}




\section{Data Analysis}

The challenges of NAEP analyses and the ways they were addressed are described briefly here (for more information, see Johnson [1992]). First, NAEP uses a multistage, stratified random sample of students and schools. Private schools were oversampled. Weights were assigned to each student and school to adjust for both unequal probabilities of selection and nonresponse. Second, to reduce the test-taking burden, no student takes the entire NAEP battery of items, and individual students are not assigned a single "score." Instead, five "plausible values" are randomly drawn from the conditional distribution of proficiency scores for each student. Hence, in NAEP achievement analyses, the results of separate analyses were obtained for each of the five plausible values and then synthesized (in accordance with Rubin [1987]).

The primary statistical analyses were conducted with HLM 6.0 (Raudenbush et al. 2004). We created two-level hierarchical linear models to examine achievement by school type while controlling for various student- and schoollevel characteristics. A school-level weight was used at level 2. The plausible values feature of HLM was used, prompting the program to run models for each of the five plausible values internally, producing their average value and correct standard errors (Raudenbush and Bryk 2002).

A sequence of HLM models was created at both the fourth and eighth grades to examine the relationship between school type and mathematics achievement, while controlling for the variables outlined above. In all of these models, binary variables were entered uncentered, while continuous variables were grand-mean centered at both the student level and at the school level. These first three models serve to simply recap the main findings from the first phase of this study and to serve as a baseline for comparison of school coefficients as other variables are added to models 4-12. As variables pertaining to school size, class size, school climate, teacher education, mathematics instruction, and student beliefs/attitudes are added to the models, we are able to determine both whether these factors correlate with achievement and the effect the addition of these factors on the school coefficients, thereby shedding light on possible explanations for school achievement differences.

Results

Basic descriptive statistics for school climate and other measures are briefly compared by school type before turning to the HLM results. In order to interpret NAEP achievement data, some information is necessary. The NAEP mathematics results are reported as scale scores, with the 2003 student scores averaging 235 at grade 4 and 278 at grade 8 . Standard deviations for school 


\section{Achievement Differences and School Type}

achievement means were 14.7 at grade 4 and 19.3 at grade 8 . In these terms, a 1-5-point difference between schools represents a small effect (roughly .1-.3 standard deviations), while a 10- or 11-point difference represents a moderateto-large effect (roughly .5-.7 standard deviations).

\section{Descriptive Results}

Descriptive results are presented in tables 1 and 2. In comparison to private schools, public schools tended to have relatively large percentages of minority students, students of limited English proficiency, students with individualized education plans, students qualified for free/reduced lunch, and those with limited home-learning resources (e.g., books, encyclopedias). There was a higher concentration of private schools in urban locations, with particular types of private schools being more concentrated in various regions of the country.

There were several differences in school climate and other administrator-, teacher-, and student-reported variables when compared by school type. Many of these differences were consistent with what others have found, such as smaller school size, higher teacher morale, more parent involvement, and less conflict in private schools, with Catholic schools appearing particularly strong on parent involvement measures (Anderson and Resnick 1997; Bryk et al. 1993; Chubb and Moe 1990b). Public and Catholic schools tended to have the largest class sizes (data available at grade 4 only), averaging between 19 and 25 students, in comparison with means of less than 16-18 students per class in Lutheran, conservative Christian, and other private schools.

One particularly striking difference by school type involved teacher credentials. The vast majority of public school students had certified teachers (89 percent at grade 4, 75 percent at grade 8), while conservative Christian schools employed relatively few such teachers, with an average of less than 45 percent. Finally, public school teachers reported participating in more forms of professional development than teachers in other schools.

There were some ways in which mathematics instruction appeared more traditional in private elementary schools than in public schools. At fourth grade, public school teachers reported a greater emphasis on calculator use and nonnumber mathematics strands (geometry, measurement, data analysis/ probability, and algebra). Still, there were no consistent differences in student beliefs and attitudes toward mathematics across the school types. However, this raises an important caution about all of these descriptive comparisons. Specifically, there are some variables under discussion, such as students' beliefs about mathematics, that consistently correlate with student SES and race/ ethnicity (Lubienski 2006). Given that private schools are disproportionately

\section{American Journal of Education}




\section{Lubienski, Lubienski, and Crane}

of high SES, relationships between school type and some variables would likely appear quite different if schools of similar SES and race/ethnicity were compared across sectors. ${ }^{6}$ Such underlying relationships are more apparent in the HLM results.

\section{HLM Results}

The results of the first three models (along with the HLM equations) were reported previously (Lubienski and Lubienski 2006) and are summarized only briefly here. According to model 1 in table 3 , the traditional HLM null model, school mathematics achievement across all schools averaged 235.9 points in fourth grade, with 29 percent of the variance in achievement between schools and 71 percent within schools. Model 2 indicates that, in comparison to public schools, fourth-grade mathematics achievement averaged 8.6 points higher in Catholic schools, roughly 11 points higher in Lutheran and other private schools, and 5 points higher in conservative Christian schools. However, model 3 reveals that after adjusting for demographic differences among schools, public school means were significantly higher than the means for all other school types, with coefficients ranging from -3.7 (Lutheran) to -11.3 (conservative Christian). With the addition of demographic variables, the model explained over 74 percent of the variance in achievement between schools and 18 percent of the variance within schools. This very large reduction in the variance between schools drastically diminishes the additional variance for which the remaining models (4-12) can account.

To help the reader interpret the results, the intercept is the estimated mean achievement of a fourth-grade student who is zero on all of the binary predictors and at the mean of all of the continuous predictors. ${ }^{7}$ As a specific example, model 3's intercept of 247.6 is the estimated mean achievement for white, non-IEP, non-LEP, lunch-ineligible males, with average home resources, in a Midwestern, suburban (or small city) public school of average minority, LEP, and SES populations. In a Catholic school of similar demographics, the estimated achievement of such a student would be 7.5 points lower, or 239.8. If the student were black instead of white, the achievement would average 15.8 points lower within the same school.

Overall, model 3 indicates that the apparent private school advantage evident in model 2 reverses after accounting for the higher proportions of advantaged students attending private schools. One can see in table 4 that the grade 8 results are similar, with public schools scoring roughly equal to or higher than the various private school types after controlling for demographics. This certainly raises the question of why public schools are scoring so well in 


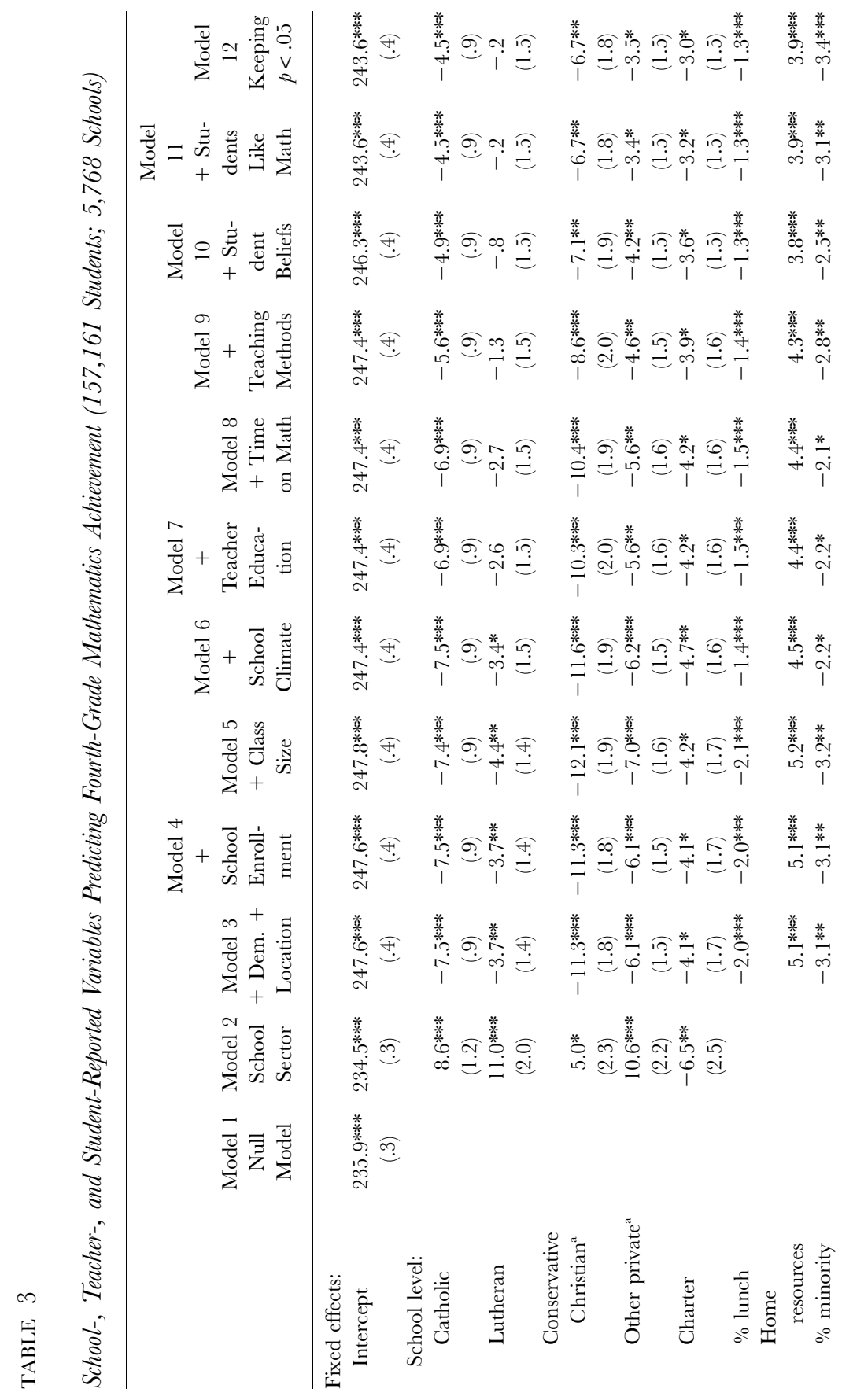




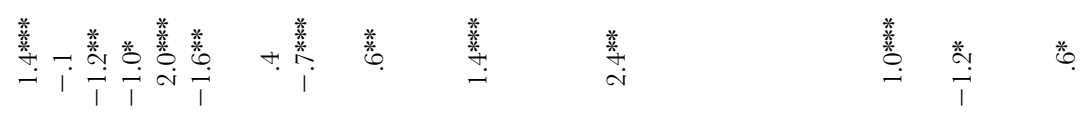

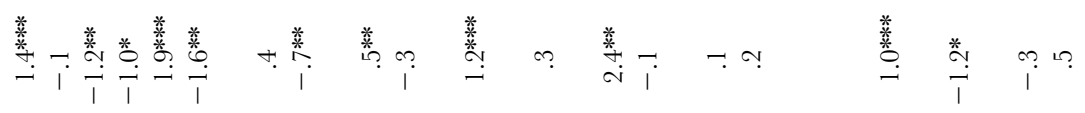

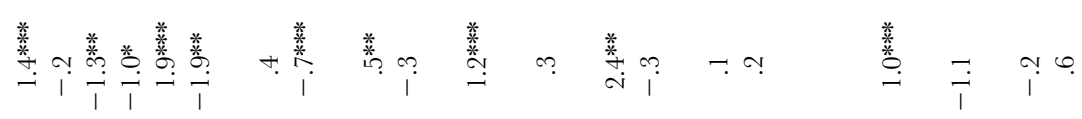

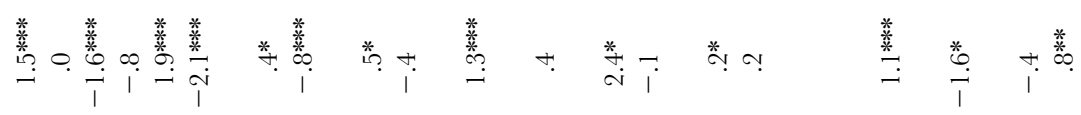

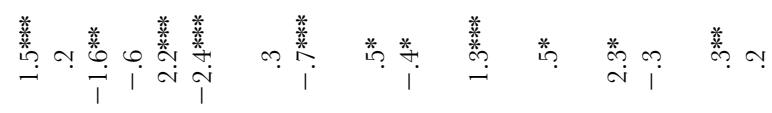

$$
\begin{aligned}
& \text { 㳯 斤 }
\end{aligned}
$$

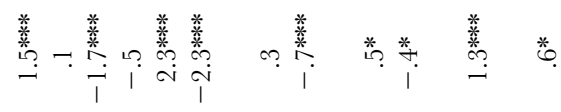

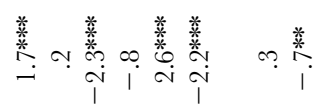

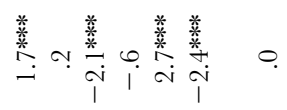

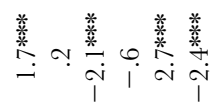

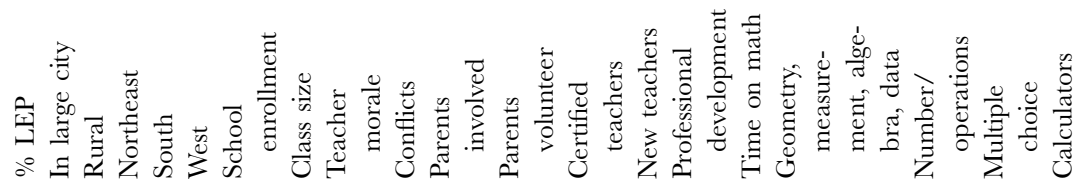

119 


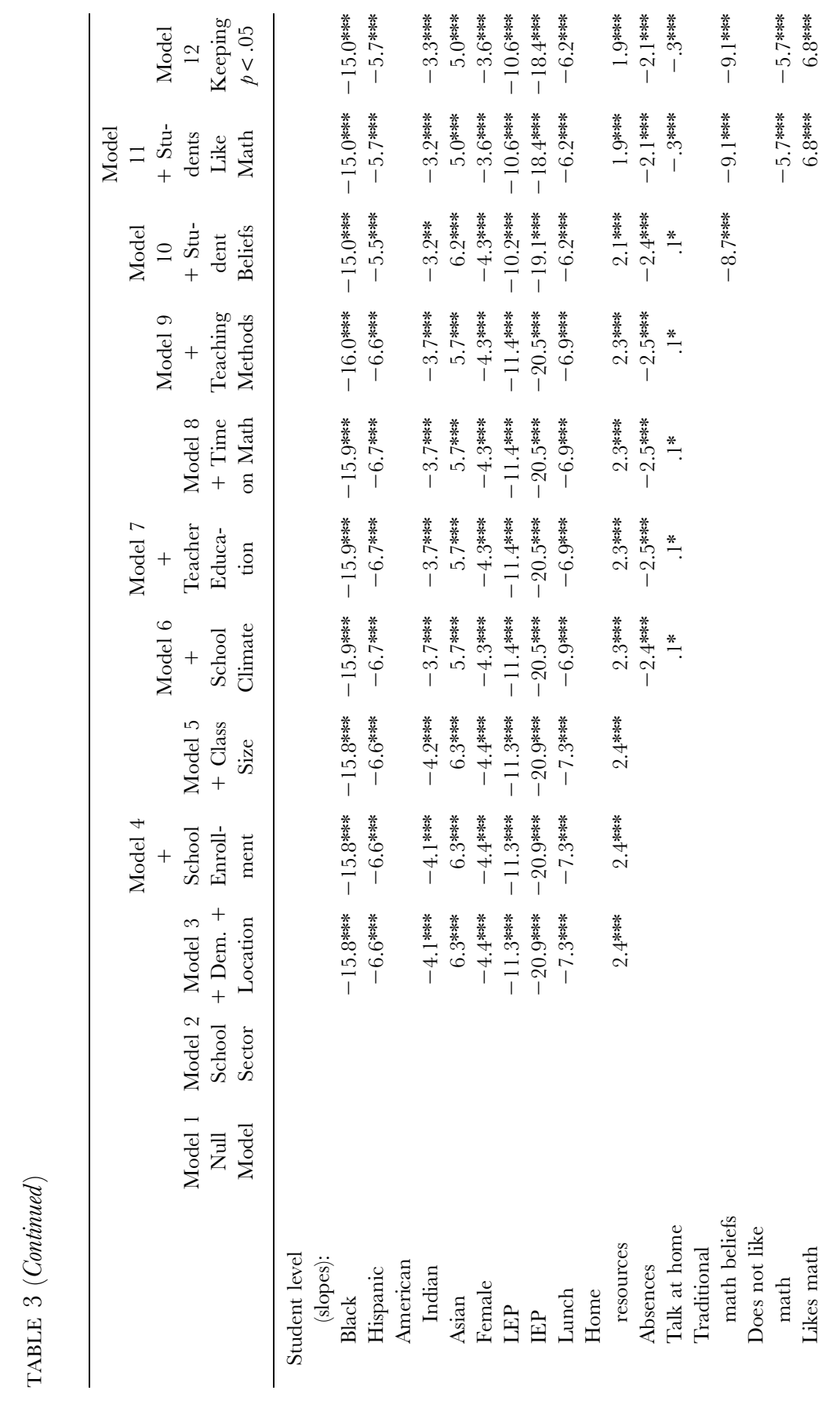




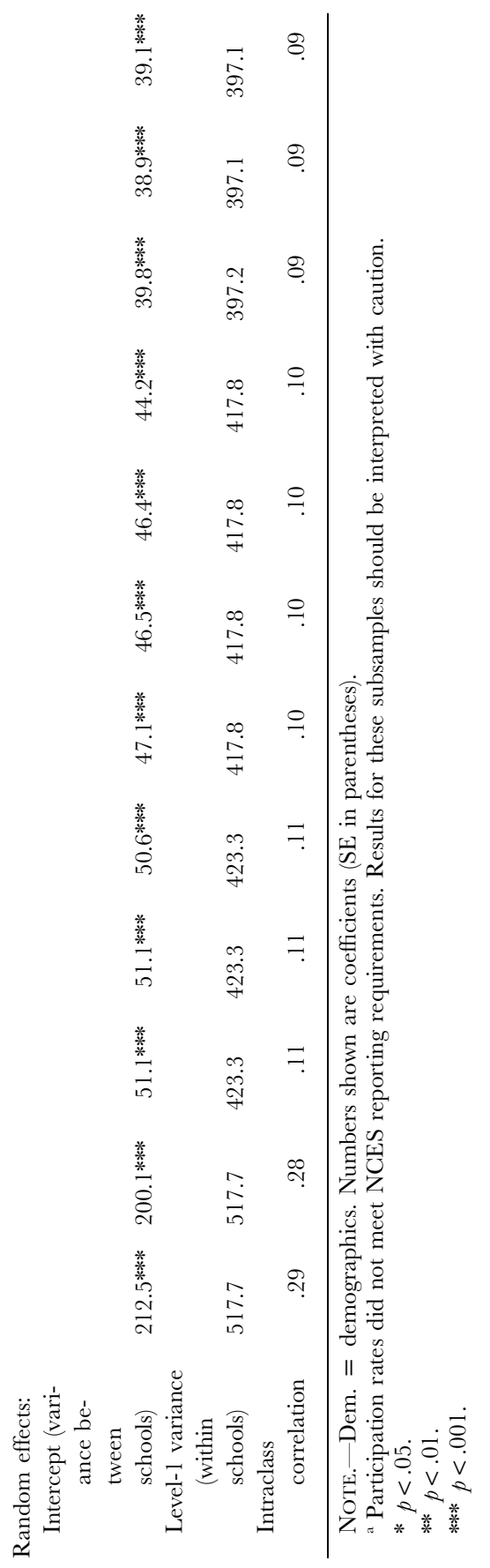




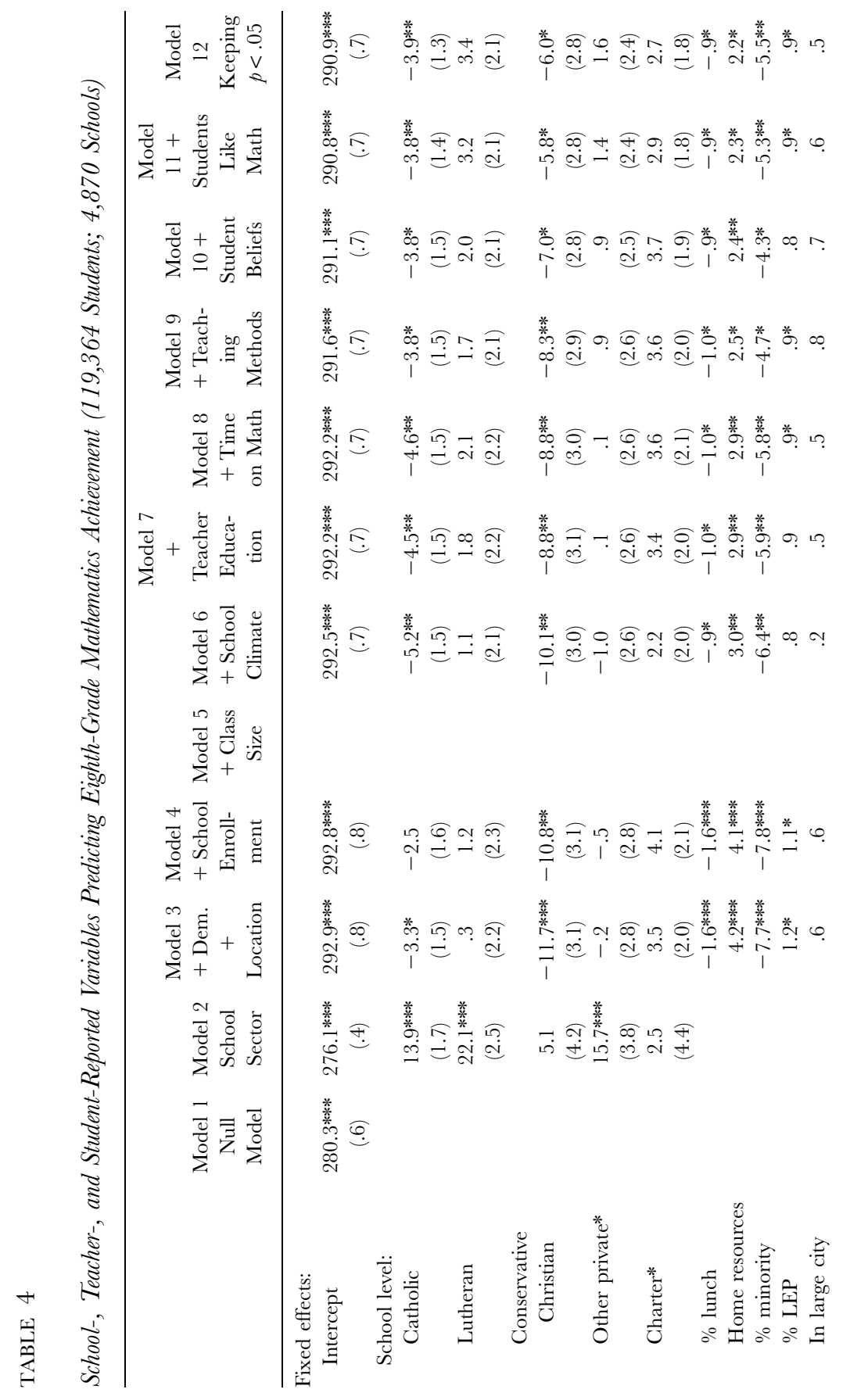




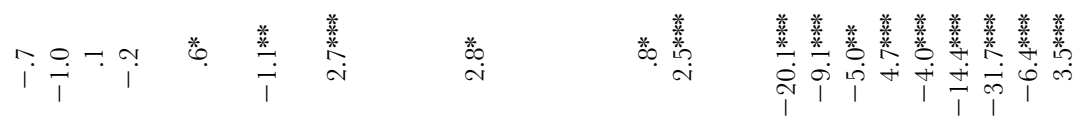

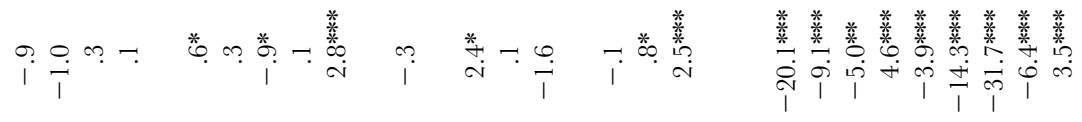

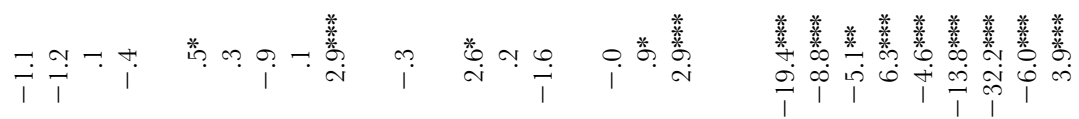

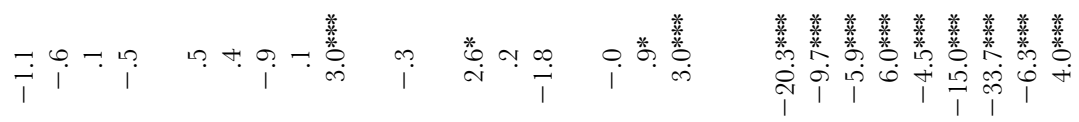

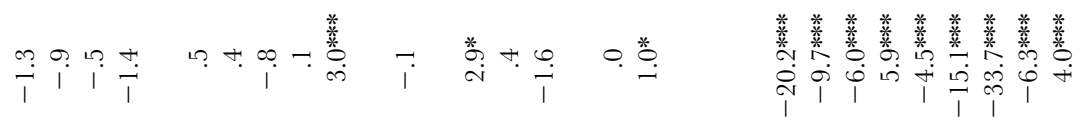

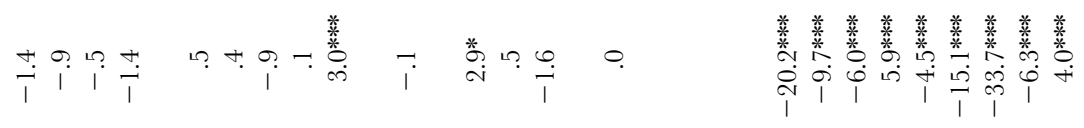

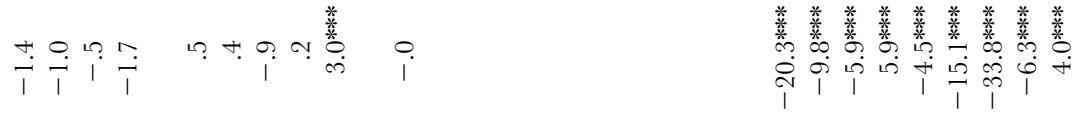

$$
\begin{aligned}
& \text { 은 운 }
\end{aligned}
$$

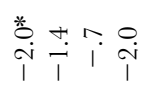

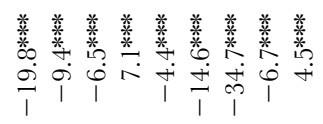

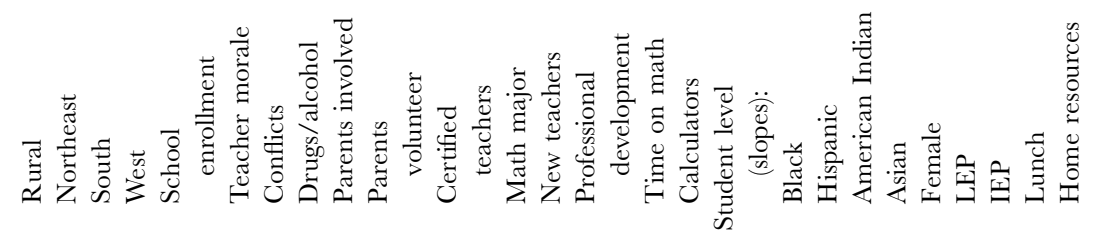




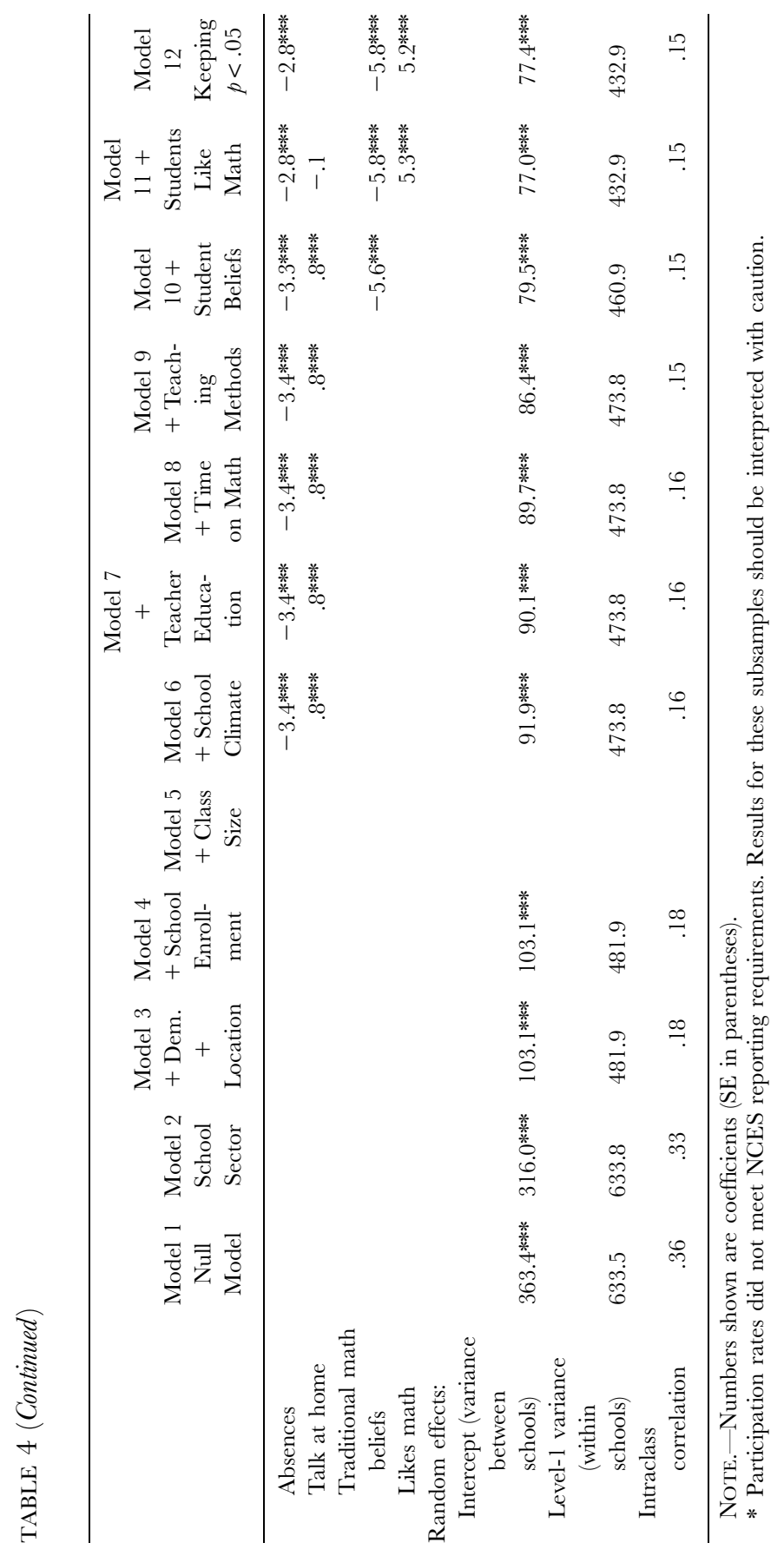


comparison with their demographically similar counterparts of other school types.

As we add variables to models 4-12 (in tables 3 and 4), we can examine the impact of various factors on the private school coefficients. If a variable correlates positively with achievement and is more prevalent in private schools than in demographically similar public schools, then the private school coefficients would decrease after adding that variable, because an "advantage" of private schools had been controlled for. For example, if smaller class size is both a predictor of achievement and more prevalent in private schools than in their public school counterparts, we would expect private school scores to decrease after we control for class size, indicating that once we hold class size constant, the disparities between public and private school achievement are even larger. On the other hand, if another variable, such as teacher certification, correlates positively with achievement, and the private school coefficients increase when the variable is added, then the variable is "explaining" some of the achievement disparities favoring public schools, revealing that it is important that more certified teachers are employed in public schools than in comparable private schools. ${ }^{8}$

Model 4 indicates that school size is not a significant predictor of achievement at either fourth or eighth grade (although it was marginally significant and crossed into statistical significance in some later models), and the addition of the variable did not account for any additional variance in achievement at either grade. Still, because it is a nearly significant, positive predictor of achievement at grade 8 , and because private schools are, on average, smaller than public schools, we see a small (less than one point) rise in most private school coefficients when comparing model 3 with model 4 in table 4 .

Model 5 (grade 4 only) indicates that class size is a significant negative predictor of achievement. As a specific example of the meaning of the -.7 coefficient, schools reporting average class sizes of greater than 25 students (five on the 1-5 scale) scored an estimated .7 points lower than demographically equivalent schools reporting class sizes of 21-24 students (four on the scale). It is important to note that the NAEP class-size variable provides only a rough proxy for the class sizes encountered by the students actually assessed; if more sensitive measures were used, it is likely that the relationship between class size and achievement would be even stronger. In comparing school-type coefficients in models 4 and 5, we see a decrease ranging from .7-.9 points for the three school types with the smallest class sizes: conservative Christian, Lutheran, and other private schools. The addition of class size explained an additional 1 percent of the remaining variance in achievement between schools.

Model 6 includes a set of school climate variables (again, very broadly defined), revealing several patterns. First, although parent involvement (i.e., participation in parent-teacher conferences, open houses, PTA) was a highly 


\section{Achievement Differences and School Type}

significant predictor of achievement at grades 4 and 8 , parents volunteering in the schools was not correlated at all with achievement at grade 8 and was barely significant (and insignificant in later models) at grade 4 . Teacher morale was positively associated with achievement, while conflicts were negatively associated; however, these relationships were significant at grade 4 only. At grade 8, drugs/alcohol was not related to achievement. Student absences were consistently, strongly negatively related to achievement in both grades, while talking about studies at home was positively correlated (although at both grades, the addition of the "I like math" variable reversed the latter correlation, indicating some collinearity issues between talking about studies at home and liking mathematics). The climate variables correlating positively with achievement tended to be those that were more prevalent in private schools. Hence, we might expect to see substantial decreases in the coefficients of the private schools when these variables are added to model 6 . However, the pattern is not consistent, indicating that although school climate factors, such as parent involvement, teacher morale, and student attendance, might seem more favorable in private schools, it appears that in many cases this might simply be due to the advantaged demographics of those schools, particularly at grade 4. However, at grade 8, Catholic schools show a 2.7 point decrease when school climate variables are included, indicating that those schools have relatively positive climates when compared to other demographically similar schools. Overall, the addition of the school climate variables explained an additional 7 percent of the remaining variance between schools and 1 percent within schools.

Model 7 adds teacher background variables, including certification, whether teachers majored or minored in mathematics (grade 8 only), whether teachers were new, and the number of different professional development activities in which teachers participated. Of these four variables, only the employment of certified teachers was a significant, positive predictor of achievement at both grades 4 and 8 . As a specific example of the meaning of the 2.3 point coefficient (2.9 at grade 8) reported in model 7, schools in which 80 percent of assessed fourth graders had certified teachers scored an average of .23 points higher than schools with only 70 percent of students with certified teachers. This appears to be a small effect, but as will be discussed later, the relationships identified here between student achievement and the teacher-reported data, in particular, are likely conservative estimates of the relationships that exist and would be identified by using more sensitive measures over time. Still, it is important to note the significant, positive relationship between fourth-grade student achievement and teachers' exposure to a variety of professional development forms (a variable that is correlated with reform-oriented student beliefs about mathematics, given the change in the professional development coefficient seen in model 10). Overall, the teacher education variables ac- 


\section{Lubienski, Lubienski, and Crane}

counted for an additional 1.3 percent of the remaining variance between schools. Despite the small amount of variance explained, there is a strikingly consistent pattern in that all of the private school coefficients increased between .6 and 1.3 points from model 6 to model 7 , with the largest increases occurring for the conservative Christian schools at both the fourth and eighth grades.

Model 8 includes the "time on math" variable, which was significant at grade 8 but not at grade 4 . This variable explained virtually no additional variance in achievement at either grade. The addition of the variable had little effect on the school-type coefficients. The weakness of this variable could be due to the insensitivity of the response scale, which topped out at "three or more hours per week."

Instruction-related variables were added to create model 9. At grade 4 these included curricular emphases, use of multiple-choice assessments, and calculator use. Of these, the strongest, most persistent predictor of achievement was teachers' emphasis on nonnumber mathematics strands. Specifically, the 1.1 coefficient indicates that if teachers in a school said they had a "strong" emphasis on geometry, measurement, algebra, and data analysis/probability (therefore averaging 12 on the 1-12 scale), the school mean was an estimated 4.4 points higher than schools in which teachers, on average, reported a "moderate" emphasis on the four strands (thereby averaging eight on the scale). Moreover, an emphasis on number/operations correlated negatively with achievement, while calculator instruction correlated positively. The effect of the addition of these variables on the fourth-grade private school coefficients was consistent, with the various private school coefficients increasing between 1.0 and 1.8 points, with the largest gain made by conservative Christian schools, whose coefficient changed from - 10.4 points in model 8 to -8.6 points in model 9 .

At grade 8, the only instruction-related variable included was a calculator composite, which was positively correlated with mathematics achievement. However, the change in private school coefficients from model 8 to model 9 was mixed. The inclusion of the teaching-related variables explained 5 percent of the remaining variance between schools at grade 4 and 4 percent at grade 8 .

Model 10 reveals that students' traditional beliefs about mathematics correlate very strongly and negatively with achievement at grades 4 and 8 (consistent with Lubienski [2006]). Private school coefficients generally increased, with conservative Christian schools again showing the greatest increases of $1.3-1.5$ points. The increases in the private school coefficients from model 9 to model 10 (with the exception of Catholic schools at grade 8) suggest that students in private schools tend to hold more traditional beliefs about mathematics than students in demographically similar public schools. Overall, the addition of student beliefs to the fourth-grade models explained an additional 


\section{Achievement Differences and School Type}

10 percent of the remaining variance between schools (8 percent at grade 8$)$, and 5 percent of the remaining variance within schools (3 percent at grade 8).

Finally, the "I like mathematics" variable was added to model 11. Liking mathematics was a significant, positive correlate of mathematics achievement at both grades. Most private school coefficients increased slightly with the addition of this variable, with Lutheran and conservative Christian schools showing the greatest gains of 1.2 points at grade 8 . This suggests that public school students tend to like mathematics more than students in demographically similar private schools. This variable explained 2-3 percent of the remaining variance between schools at grades 4 and 8, 6 percent within schools at grade 8 , but no additional within-school variance at grade 4 .

The final model 12 retained all school-type and demographic/location variables, as well as those school size, climate, and instruction-related variables (from models $4-11)$ that were significant $(p<.05) .{ }^{9}$ This final model is slightly weaker than model 11 in terms of explaining variance but is more parsimonious in its inclusion of only those school climate/instruction-related variables that are statistically significant. ${ }^{10}$ Overall, the final model explains 82 percent of the between-school variance and 23 percent of the within-school variance, or 40 percent of the total variance in achievement.

It is important to note that across all of the models, large race-related and SES-related inequities persisted across all schools types. For example, within schools, black fourth graders scored an average of $15-16$ points (20 points at grade 8) lower than their white peers of similar SES, LEP, and disability status across all 12 models. Overall, demographic issues accounted for the vast majority of the variance in achievement between schools, while school type accounted for very little (and would likely account for even less if added at the end of the series of models instead of the beginning). School climate and instruction-related factors explained roughly $5-7$ percent of the total variance between schools, or 20-25 percent of the between-school variance that remained after adding demographics and school type.

\section{Discussion}

Factors consistently associated with higher achievement across the various models are summarized in table 5. These factors include smaller class sizes (available at grade 4 only), traditional forms of parent involvement (e.g., attendance at school meetings), student attendance, teacher certification, and various measures of reform-oriented mathematics instruction, including more calculator use (strongest at grade 8), nonnumber curricular emphases (available at grade 4 only), and students' reform-oriented beliefs about mathematics.

Some of these aspects appeared to be advantageous in private schools, 
Lubienski, Lubienski, and Crane

TABLE 5

Summary of Relationships Identified in HLM Models

\begin{tabular}{|c|c|}
\hline Predictor of Achievement & Factors \\
\hline \multicolumn{2}{|l|}{ Consistent, significant predictors: } \\
\hline $\begin{array}{l}\text { Raised most private school coeffi- } \\
\text { cients (more prevalent in public } \\
\text { schools) }\end{array}$ & $\begin{array}{l}\text { - Teacher certification } \\
\text { - Reform-oriented instruction (nonnum- } \\
\text { ber emphasis, calculator use) } \\
\text { - Students' reform-oriented beliefs } \\
\text { - Students liking mathematics }\end{array}$ \\
\hline $\begin{array}{l}\text { Mixed effect on private school } \\
\text { coefficients }\end{array}$ & $\begin{array}{l}\text { - Some school climate measures (paren- } \\
\text { tal involvement, student attendance) }\end{array}$ \\
\hline $\begin{array}{l}\text { Lowered most private school coeffi- } \\
\text { cients (more prevalent in private } \\
\text { schools) }\end{array}$ & $\begin{array}{l}\text { - Smaller class size (available at grade } 4 \\
\text { only) }\end{array}$ \\
\hline $\begin{array}{l}\text { Mixed or marginally significant } \\
\text { predictors }\end{array}$ & $\begin{array}{l}\text { - School size (slightly positively } \\
\text { associated) } \\
\text { - Some school climate measures (teacher } \\
\text { morale, conflicts, parent volunteers, } \\
\text { talk at home) } \\
\text { - Professional development }\end{array}$ \\
\hline Generally not significant predictors & $\begin{array}{l}\text { - Time on math } \\
\text { - Drugs/alcohol } \\
\text { - Teachers have math major/minor } \\
\text { (available at grade } 8 \text { only) } \\
\text { - New teachers } \\
\text { - Use of multiple choice tests }\end{array}$ \\
\hline
\end{tabular}

according to the raw data in tables 1 and 2, including parent involvement and other school climate variables. However, as noted previously, several private school coefficients increased slightly instead of decreasing, as we would have expected, when moving from model 5 to model 6 , suggesting that the more positive school climates are due more to the school demographics than to school type.

Another characteristic that was both associated with achievement and more prevalent in private schools was smaller class size - a school resource issue at the heart of much debate. When comparing coefficients between models 4 and 5 (grade 4 only), we do see the expected decrease in many private school coefficients, confirming that class sizes are, indeed, smaller in most private schools when compared with demographically similar public schools.

Still other variables did not show a consistent relationship with achievement. These variables include school size, time spent on mathematics instruction, 


\section{Achievement Differences and School Type}

and several teacher characteristics, including teaching experience, professional development, and mathematics major/minor. We must caution readers to consider the nature of these variables as measured by NAEP before jumping to conclusions about these factors being unrelated to achievement. For example, as noted previously, some of NAEP's response categories were rough and might not have captured important differences. Additionally, our models tested for linear relationships between these variables and achievement, while some other relationship might have existed (e.g., a curvilinear relationship between school size and achievement, as found by Lee and Smith [1997]). For teacher-reported characteristics, which were aggregated to the school level, the variables used were rough proxies of students' exposure to various types of teachers.

Still, the variables of most interest for the purposes of this study are those that are both associated with achievement and less prevalent in private schools, thereby shedding light on the primary question of this study, which was why most private school coefficients were lower than those of demographically similar public schools. The series of models were designed to reveal which variables caused a lessening of the public-private school achievement gaps evident in model 3. These gaps did diminish to varying extents after the inclusion of teacher background, instructional methods, and student affect variables, suggesting that these variables help explain the differences between achievement in public and private schools. For example, the fourth-grade Catholic school coefficients increased from -7.5 (in model 3) to -5.6 (model 9), mostly due to the inclusion of variables related to teacher background and instruction. This coefficient was raised further to -4.5 (model 11) with the inclusion of student beliefs and attitudes regarding mathematics. The Lutheran fourth-grade coefficient rose from -3.7 (model 3) to essentially zero in the final model. For conservative Christian schools, the fourth-grade coefficient increased from -11.3 (model 3), to -6.7 in the final model, with similar changes at grade $8 .{ }^{11}$ Hence, teacher certification, reform-oriented instruction, and student beliefs/attitudes do appear to "explain" a substantial portion of the negative private school coefficients evident in model 3. However, major portions of the coefficients remain unexplained, particularly for conservative Christian and Catholic schools.

\section{Limitations}

The NAEP's large numbers of participating students and schools, as well as the consistency of this study's results across fourth and eighth grades, provide support for the reliability of the findings reported here. Still, there are several limitations of any analysis of NAEP. 


\section{Lubienski, Lubienski, and Crane}

First, many potentially important variables are not included in NAEP. Additionally, as noted previously, missing data limited the HLM samples somewhat, especially for conservative Christian and other private schools.

Another important limitation is that NAEP data are cross-sectional - not longitudinal. Hence, we cannot draw firm conclusions about whether differences in school type, climate, or instruction "caused" achievement disparities or to what extent the causal order might have been reversed.

Another caution is that the HLM models assume linear relationships between continuous predictors (such as SES measures) and student outcomes. Our analysis of the 2000 NAEP data indicated that the relationship between school type and student achievement was, indeed, consistent across SES quartiles (Lubienski and Lubienski 2005). Still, the numbers of low-SES private school students are relatively small, and future analyses should consider this issue further, possibly using propensity scores.

Self-reported data were collected from fourth- and eighth-grade teachers and aggregated to the school level, providing only a rough proxy of students' experiences. If we had accurate measures of student achievement gains linked with the duration of exposure that students had to particular instructional practices, it is likely that we would see a greater impact on both student achievement and private school coefficients than what is suggested here (Rowan et al. 2002). On the other hand, standard errors for instruction-related coefficients were perhaps smaller than they would have been if the clustering of students within classrooms was accounted for in the models (i.e., if teachers could have been treated at a "classroom level").

Overall, the results of this study should be viewed as suggestive of relationships that should be examined further using longitudinal methods that can take student, teacher/classroom, and school levels into consideration. Still, it is also important to note that longitudinal studies suffer from attrition problems and tend to have far more limited sample sizes than those in NAEP, making it difficult for longitudinal studies alone to answer the many questions raised and examined here.

Implications

Overall, this study revealed some strikingly consistent findings between grades 4 and 8 , pointing to reasons why private school scores may be lower than those of demographically similar public schools. The first is the employment of certified teachers. After controlling for demographic differences, the schools with the lowest mean achievement, conservative Christian schools (see model 3 in tables 3 and 4), also employed the smallest percentage of certified teachers, with less than 45 percent of their fourth and eighth graders having a certified 


\section{Achievement Differences and School Type}

teacher. When teacher qualifications were controlled (see model 7), the coefficients for these schools increased from -11.6 to -10.3 at grade 4 and from -10.1 to -8.8 at grade 8 . The "teacher certification" variable might actually be serving as a proxy for some other school or administrator characteristic, such as teacher salaries or administrator ideals. However, given that the two other teacher qualification variables (professional development and "new teachers") that might also correlate with such confounding variables did not show substantial relationships with achievement in this study, it appears more likely that the presence of certified teachers was directly related to achievement. Longitudinal studies with more sensitive measures of students' exposure to such teachers over time are needed to examine the extent of the impact of certification on student achievement.

The second factor is the more prevalent use of reform-oriented mathematics instruction in public schools. National mathematics education reforms prompted by leading scholars and teachers, coupled with the alignment of the Main NAEP assessment with these changes, could be one explanation for why unexpected public-private school differences are surfacing now, in apparent contrast to the findings of earlier studies. ${ }^{12}$ The HLM results indicate that reform-oriented instructional measures, such as an emphasis on nonnumber curricular strands and the inclusion of calculators in mathematics instruction are significantly, positively correlated with school achievement. Moreover, reform-oriented mathematics beliefs among students were strongly, positively correlated with achievement. However, again, the causal order, particularly between beliefs and achievement, is unclear. Still, it is clear from the HLM results that public school students are more likely to encounter some key aspects of reform-oriented instruction and to have less rigid, traditional beliefs about mathematics, when compared with their peers in demographically similar private schools. The increase in most private school coefficients after teaching methods and student beliefs were added to the models indicates a relatively traditional mathematics instructional climate in those schools and suggests that differential use of reform-oriented practices may be one reason why public school achievement is higher than that of demographically similar private schools.

Overall, this study provides strong, nationally representative evidence that teacher certification and some reform-oriented instructional practices both correlate positively with achievement and are more prevalent in public schools than in their demographically similar private counterparts.

The findings regarding teacher certification have significant implications for current debates on school reform. Even with the rough certification measure employed in this study, the relative lack of certified teachers in private schools explained a portion of their deficit in student achievement. These findings raise questions about alternative certification paths, particularly those 


\section{Lubienski, Lubienski, and Crane}

designed to circumvent the core content and experiences offered in existing programs.

Moreover, the adoption of reform-oriented mathematics instruction appears to be an important factor in understanding the relatively high achievement in public schools. The schools where these reforms are being implemented generally appear to be achieving at higher levels. Private school teachers, who tend to have more autonomy to choose their own curricular goals and materials (Alt and Peter 2002), were less likely to emphasize the five mathematics strands promoted by NCTM and were more likely to have students who expressed traditional beliefs about the nature of mathematics.

Although greater autonomy among school administrators and teachers is often viewed as a benefit of private schools, this study points toward some potential drawbacks. This study's main findings regarding teacher certification and reform-oriented instruction suggest that reforms capitalizing on current professional expertise hold promise for improving student learning, particularly on assessments that are shaped by that expertise. School reforms that allow or even encourage schools to ignore existing national expertise regarding mathematics curriculum, instruction, and teacher education seem potentially detrimental. Overall, this study suggests that institutional-level reforms such as school choice and deregulation - based on assumptions regarding the superiority of private-style structural models - might not produce the benefits that some reformers have anticipated.

Notes

This project was funded through a National Assessment of Educational Progress Secondary Analysis grant (R902B05017) from the Institute of Education Sciences, National Center for Education Statistics. The authors would like to thank Eric Camburn, Jay Verkuilen, and $A \mathcal{F} E$ 's reviewers for their helpful comments on this work. Of course, only the authors are responsible for the analyses and interpretations presented in this article.

1. In order to meet NCES reporting standards, a sample must have a 70 percent participation rate among originally selected schools. However, NAEP's resampling of demographically similar schools to replace nonrespondents, along with the use of school weights, diminishes the bias resulting from nonresponse. We decided to include all of the data in our analyses to provide as much information as possible on patterns in public and private school achievement.

2. Tables A1-A4 in the appendix (available online) contain detailed descriptive statistics for the HLM samples, including comparisons between the HLM and full NAEP samples by school type. Overall, most demographic differences between the HLM and full samples within the various school types were small, typically varying by less than a few percentage points.

3. Charter schools were not included in the public school sample. Achievement results for charter schools were discussed in Lubienski and Lubienski (2006).

NOVEMBER 2008 


\section{Achievement Differences and School Type}

4. These terms are used to be consistent with NAEP.

5. In order to preserve data, the variable "percent eligible for school lunch" was imputed based on student home environment variables for those schools that did not report this information (similar to the method described previously for the studentlevel imputation).

6. For this reason, statistical differences among the many measures in tables 1 and 2 are not discussed here. For a more detailed descriptive comparison of NAEP data by private school type, see Broughman and Pugh (2004). Interested readers can also utilize the Web-based NAEP Data Explorer (http://nces.ed.gov/nationsreportcard/ nde) to create additional tables of descriptive data by school type.

7. In all of the HLM models, binary variables were entered uncentered, and the remaining variables (italicized below) were entered grand-mean centered. The HLM equations for model 3 were as follows (additional variables were added to the level-1 and level-2 equations to create models $4-12$, as indicated in tables 3 and 4): level-1 model: $\mathrm{Y}=\mathrm{B} 0+\mathrm{B} 1 \times(\mathrm{BLACK})+\mathrm{B} 2 \times(\mathrm{HISP})+\mathrm{B} 3 \times($ INDIAN $)+\mathrm{B} 4 \times$ $($ ASIAN $)+\mathrm{B} 5 \times($ FEMALE $)+\mathrm{B} 6 \times($ LEP $)+\mathrm{B} 7 \times($ IEP $)+\mathrm{B} 8 \times($ LUNCH $)+$ B9 $\times($ HOME RESOURCES $)+\mathrm{R}$; level-2 model: $\mathrm{B} 0=\mathrm{G} 00+\mathrm{G} 01 \times(\mathrm{CATHOLIC})$ + G02 $\times$ (LUTHERAN) + G03 $\times$ (CONSERVATIVE CHRISTIAN) + G04 $\times$ $($ OTHER PRIVATE $)+$ G05 $\times($ CHARTER $)+\mathrm{G} 06 \times(\% L U N C H)+\mathrm{G} 07 \times$ $($ MEAN HOME RESOURCES $)+\mathrm{G} 08 \times(\%$ MINORITY $)+\mathrm{G} 09 \times(\%$ LEP $)+\mathrm{G} 010$ $\times($ LARGE CITY $)+$ G011 $\times($ RURAL $)+$ G012 $\times($ NORTHEAST $)+$ G013 $\times$ $(\mathrm{SOUTH})+\mathrm{G} 014 \times($ WEST $)+\mathrm{U} 0$.

8. The term "comparable" here indicates that the schools are similar on all measures entered into the HLM models thus far.

9. Issues of multiple comparisons merit consideration due to the inclusion of over a dozen different school- and instruction-related variables in models 4-10. Given that variables were included at two different levels (student and school) and at two different grades (fourth and eighth), there are likely differing opinions regarding exactly how the issue of multiple comparisons should be addressed. For this reason, the common standard of .05 is used, but three different significance levels are denoted (.05, .01, and .001), and in drawing conclusions from this study, we emphasize those variables that consistently showed significance at both fourth and eighth grades (when possible).

10. Due to the limitations of the HLM software when working with plausible values, deviance statistics could not be computed, and the differences in variance explained by the models were not tested for statistical significance. Given the cross-sectional nature of the NAEP data, the coefficients in the various models should be viewed as suggestive of relationships that exist and that would likely be stronger if NAEP had more sensitive measures of students' experiences and achievement in the schools over time. Additionally, given that the vast majority of schools are public and had relatively little variation in key aspects such as teacher certification, it is not surprising that the percentage of variance explained by such variables is small. The purpose of this study is not to provide definitive measures of the exact strength of the relationships between the variables and the differences between models but, instead, to identify factors that might explain the rather surprising disparities found between public and private school achievement scores in the first phase of this study.

11. The increase in the private school coefficients were even greater when using model 5 (which controls for class size) as the point of comparison with the final model. For example, the Lutheran coefficient increases from -4.4 (in model 5) to roughly zero in the final model, and the conservative Christian coefficient increases from -12.1 to -6.7 .

12. As discussed in more detail in Lubienski and Lubienski (2006), there are other 


\section{Lubienski, Lubienski, and Crane}

possible explanations, including the fact that prior studies tended to examine high school achievement, while this study focused on earlier grades.

\section{References}

Alt, Martha N., and Katharine Peter. 2002. Private Schools: A Brief Portrait (NCES 2002 013). National Center for Education Statistics, U.S. Department of Education, Washington, DC.

Anderson, Karen M., and Michael A. Resnick. 1997. Careful Comparisons: Public and Private Schools in America. Alexandria, VA: National School Boards Association.

Bandura, Albert. 1993. "Perceived Self-Efficacy in Cognitive Development and Functioning." Educational Psychologist 28 (2): 117-48.

Benveniste, Luis, Martin Carnoy, and Richard Rothstein, eds. 2003. All Else Equal: Are Public and Private Schools Different? New York: Routledge Falmer.

Braswell, James S., Mary C. Daane, and Wendy S. Grigg. 2003. The Nation's Report Card: Mathematics Highlights 2003. Washington, DC: U.S. Department of Education, Institute for Education Sciences, National Center for Education Statistics.

Braun, Henry, Frank Jenkins, and Wendy Grigg. 2006. Comparing Private Schools and Public Schools Using Hierarchical Linear Modeling (NCES 2006-461). Washington, DC: National Center for Education Statistics.

Broughman, Stephen P., and Kathleen W. Pugh. 2004. Characteristics of Private Schools in the United States: Results from the 2001-2002 Private School Universe Survey (NCES 2005305). Washington, DC: U.S. Department of Education, National Center for Education Statistics.

Bryk, Anthony S., Valerie E. Lee, and Peter B. Holland. 1993. Catholic Schools and the Common Good. Cambridge, MA: Harvard University Press.

Bryk, Anthony S., and Barbara L. Schneider. 2002. Trust in Schools. New York: Russell Sage Foundation

Carbonaro, William. 2006. "Public-Private Differences in Achievement among Kindergarten Students: Differences in Learning Opportunities and Student Outcomes." American Fournal of Education 113 (1): 31-65.

Carpenter, Thomas P., Elizabeth Fennema, Penelope L. Peterson, Chi-Pang Chiang, and Megan Loef. 1989. "Using Knowledge of Children's Mathematics Thinking in Classroom Teaching: An Experimental Study." American Educational Research Fournal 26:499-531.

Chandler, Louis. 1999. Traditional Schools, Progressive Schools: Do Parents Have a Choice? Washington, DC: Thomas B. Fordham Foundation.

Choy, Susan P. 1997. "Public and Private Schools: How Do They Differ? Findings from 'The Condition of Education, 1997' No. 12." MPR Associates, Berkeley, CA.

Chubb, John E., and Terry M. Moe. 1990a. "America's Public Schools: Choice Is a Panacea." Brookings Review 8 (3): 4-12.

Chubb, John E., and Terry M. Moe. 1990b. Politics, Markets, and America's Schools. Washington, DC: Brookings Institution.

Cohen, David K., and Heather C. Hill. 2001. Learning Policy: When State Education Reform Works. New Haven, CT: Yale University Press.

Coleman, James S., and Thomas Hoffer. 1987. Public and Private High Schools: The Impact of Communities. New York: Basic.

Coleman, James S., Thomas Hoffer, and Sally Kilgore. 1982. High School Achievement: Public, Catholic, and Private Schools Compared. New York: Basic. 


\section{Achievement Differences and School Type}

Comer, James P. 2005. "The Reward of Parent Participation.” Educational Leadership 62 (6): 38-42.

Darling-Hammond, Linda. 2000. "Teacher Quality and Student Achievement: A Review of State Policy Evidence." Education Policy Analysis Archives 8 (1), http://epaa .asu.edu/epaa/v8n1/.

Davies, Scott, and Linda Quirke. 2004. "The New Institutionalism, Market Theory, and Private Schools: How Institutions Shape Choice." Paper presented at the annual meetings of the American Sociological Association, August, San Francisco.

Finn, Jeremy D., and Charles M. Achilles. 1999. "Tennessee's Class Size Study: Findings, Implications, Misconceptions." Educational Evaluation and Policy Analysis 21 (2): 97-110.

Finn, Jeremy D., and Kristin E. Voelkl. 1993. "School Characteristics Related to Student Engagement." Journal of Negro Education 62 (3): 249-68.

Goddard, Roger D., Wayne K. Hoy, and Anita Woolfolk Hoy. 2000. "Collective Teacher Efficacy: Its Meaning, Measure, and Impact on Student Achievement." American Educational Research Fournal 37 (2): 479-508.

Goldhaber, Dan D., and Dominic J. Brewer. 2000. "Does Teacher Certification Matter? High School Teacher Certification Status and Student Achievement." Educational Evaluation and Policy Analysis 22 (2): 129-45.

Greenwald, Rob, Larry V. Hedges, and Richard D. Laine. 1996. "The Effect of School Resources on School Achievement." Review of Educational Research 66:361-96.

Hanushek, Eric A. 1996. "A More Complete Picture of School Resource Policies." Review of Educational Research 66:397-409.

Hanushek, Eric A. 1999. "Some Findings from an Independent Investigation of the Tennessee Star Experiment and from Other Investigations of Class Size Effects." Educational Evaluation and Policy Analysis 21 (2): 143-64.

Henderson, Anne T., and Karen L. Mapp. 2002. A New Wave of Evidence: The Impact of School, Family, and Community Connections on Student Achievement. Austin, TX: National Center for Family and Community Connections with Schools.

Hess, Frederick M. 2006. Tough Love for Schools: Essays on Competition, Accountability, and Excellence. Washington, DC: AEI Press.

Heyneman, Stephen P. 2005. "Student Background and Student Achievement: What Is the Right Question?" American Fournal of Education 112 (1): 1-9.

Hill, Heather, Brian Rowan, and Deborah L. Ball. 2005. "Effects of Teachers' Mathematical Knowledge for Teaching on Student Achievement." American Education Research Fournal 42 (2): 371-406.

Howley, Craig B., and Aimee A. Howley. 2004. "School Size and the Influence of Socioeconomic Status on Student Achievement: Confronting the Threat of Size Bias in National Data Sets.” Education Policy Analysis Archives 12 (52), http://epaa.asu.edu/ epaa/v12n52/.

Hoxby, Caroline M. 2000. "The Effects of Class Size on Student Achievement: New Evidence from Population Variation." Quarterly Fournal of Economics 115 (4): 1239-85.

Hoy, Wayne K., John C. Tarter, and Anita Woolfolk Hoy. 2006. "Academic Optimism of Schools: A Force for Student Achievement." American Educational Research Fournal 43 (3): 425-46.

Ingersoll, Richard M. 2001. "Teacher Turnover and Teacher Shortages: An Organizational Analysis." American Educational Research Fournal 38 (3): 499-534.

Johnson, Eugene G. 1992. "The Design of the National Assessment of Educational Progress." Fournal of Educational Measurement 29 (2): 95-110.

Kloosterman, Peter, and Frank K. Lester Jr., eds. 2004. Results and Interpretations of the 


\section{Lubienski, Lubienski, and Crane}

1990 through 2000 Mathematics Assessments of the National Assessment of Educational Progress. Reston, VA: National Council of Teachers of Mathematics.

Krueger, Alan B., and Diane M. Whitmore. 2001. "The Effect of Attending a Small Class in the Early Grades on College-Test Taking and Middle School Test Results: Evidence from Project STAR." Economic Fournal 111 (468): 1-17.

Lee, Jung-Sook, and Natasha K. Bowen. 2006. "Parent Involvement, Gultural Capital, and the Achievement Gap among Elementary School Children." American Educational Research Fournal 43 (2): 193-218.

Lee, Valerie E. 2004. "Effects of High-School Size on Student Outcomes: Response to Howley and Howley." Education Policy Analysis Archives 12 (53), http://epaa.asu.edu/ ераa/v12n53/.

Lee, Valerie E., and Julia B. Smith. 1997. "High School Size: Which Works Best, and for Whom?" Educational Evaluation and Policy Analysis 19 (3): 205-27.

Loveless, Tom, and Paul Diperna. 2000. How Well Are American Students Learning? Focus on Math Achievement. Brown Center Report, vol. 1, no. 1. Washington, DC: Brookings Institution.

Lubienski, Christopher, Corinna C. Crane, and Sarah T. Lubienski. 2008. "What Do We Know about School Effectiveness? Academic Gains in Public and Private Schools." Phi Delta Kappan 89 (9): 689-95.

Lubienski, Sarah Theule. 2006. "Examining Instruction, Achievement, and Equity with NAEP Mathematics Data." Education Policy Analysis Archives 14 (14), http:// epaa.asu.edu/epaa/v14n14/.

Lubienski, Sarah Theule, and Christopher Lubienski. 2005. "A New Look at Public and Private Schools: Student Background and Mathematics Achievement." Phi Delta Kappan 86 (9): 696-99.

Lubienski, Sarah Theule, and Christopher Lubienski. 2006. "School Sector and Academic Achievement: A Multi-Level Analysis of NAEP Mathematics Data." American Educational Research Fournal 43 (4): 651-98.

McEwan, Patrick J. 2000. "The Potential Impact of Large-Scale Voucher Programs." Review of Educational Research 70 (2): 103-49.

Moe, Terry M. 2005. "A Highly Qualified Teacher in Every Classroom.” In Within Our Reach: How America Can Educate Every Child, ed. J. E. Chubb. Lanham, MD: Rowman \& Littlefield.

Monk, David H. 1994. "Subject Area Preparation of Secondary Mathematics and Science Teachers and Student Achievement." Economics of Education Review 13 (2): $125-45$.

Mosteller, Frederick. 1996. "The Tennessee Study of Class Size in the Early School Grades." Future of Children 5 (2): 113-27.

NCTM (National Council of Teachers of Mathematics). 1989. Curriculum and Evaluation Standards for School Mathematics. Reston, VA: National Council of Teachers of Mathematics.

NCTM (National Council of Teachers of Mathematics). 2000. Principles and Standards for School Mathematics. Reston, VA: National Council of Teachers of Mathematics.

Newmann, Fred M., and Gary G. Wehlage. 1995. Successful School Restructuring: A Report to the Public and Educators. Madison, WI: Center on Organization and Restructuring of Schools.

Raudenbush, Stephen W., and Anthony S. Bryk. 2002. Hierarchical Linear Models: Applications and Data Analysis Methods. 2nd ed. Thousand Oaks, CA: Sage.

Raudenbush, Stephen W., Anthony S. Bryk, Yuk F. Cheong, Richard T. Congdon, and Mathilda du Toit. 2004. HLM 6: Linear and Nonlinear Modeling. Lincolnwood, IL: Scientific Software International. 


\section{Achievement Differences and School Type}

Raudenbush, Stephen W., Randall P. Fotiu, and Yuk F. Cheong. 1998. "Inequality of Access to Educational Opportunity: A National Report Card for Eighth Grade Math." Educational Evaluation and Policy Analysis 20:253-68.

Reardon, S. F., J. E. Cheadle, and J. P. Robinson. 2008. "The Effect of Catholic Schooling on Math and Reading Development in Kindergarten through Fifth Grade." Paper presented at the annual meeting of the Society for Research on Educational Effectiveness, March 2-4, Crystal City, VA.

Riordan, Julie E., and Pendred E. Noyce. 2001. "The Impact of Two Standards-Based Mathematics Curricula on Student Achievement in Massachusetts." Fournal for Research in Mathematical Education 32 (4): 368-98.

Rothstein, Richard, Martin Carnoy, and Luis Benveniste. 1999. Can Public Schools Learn from Private Schools? Washington, DC: Economic Policy Institute and the Aspen Institute.

Rowan, Brian, Richard Correnti, and Robert J. Miller. 2002. "What Large-Scale Survey Research Tells Us about Teacher Effects on Student Achievement: Insights from the Prospects Study of Elementary Schools.” Teachers College Record 104:1525-67.

Rubin, Donald B. 1987. Multiple Imputation for Nonresponse in Surveys. New York: Wiley.

Schoenfeld, Alan H. 2002. "Making Mathematics Work for All Children: Issues of Standards, Testing, and Equity." Educational Researcher 31 (1): 13-25.

Scott, Leslie A., Donald A. Rock, Judith M. Pollack, and Steven J. Ingels. 1995. Two Years Later: Cognitive Gains and School Transitions of Nels:88 Eighth Graders. Statistical Analysis Report no. 95-436. Washington, DC: National Center for Education Statistics.

Senk, Sharon L., and Denisse R. Thompson, eds. 2003. Standards-Based School Mathematics Curricula: What Are They? What Do Students Learn? Hillsdale, NJ: Lawrence Erlbaum.

Smith, Kevin B. 2003. The Ideology of Education: The Commonwealth, the Market, and America's Schools. Albany, NY: SUNY Press.

Taningco, Maria T. 2006. "Assessing the Effects of Parental Decisions about School Type and Involvement on Early Elementary Education." PhD diss., Pardee Rand Graduate School, http://www.rand.org/pubs/rgs_dissertations/RGSD205/.

U.S. Department of Education. 2004. The Nation's Report Card: America's Charter Schools (NCES 2005-456). Washington, DC: National Assessment of Educational Progress.

Walberg, Herbert J., and Joseph L. Bast. 2003. Education and Capitalism: How Overcoming Our Fear of Markets and Economics Can Improve America's Schools. Stanford, CA: Hoover Institution.

Wayne, Andrew J., and Peter Youngs. 2003. "Teacher Characteristics and Student Achievement Gains: A Review." Review of Educational Research 73 (1): 89-122. 